\title{
Glass Beads in Ancient India and Furnace-Wound Beads at Purdalpur: An Ethnoarchaeological Approach
}

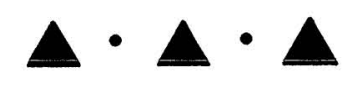

\author{
ALOK KUMAR KANUNGO
}

THE PRODUCTION OF GLASS WAS ONE OF THE MOST ADVANCED TECHNICAL processes of the ancient world. Most of the early evidence for glass has been in the form of beads. In India, glass is reported from about 200 archaeological sites (Kanungo 2002a:121) starting from the early Iron Age period, with the exception of four beads from the Chalcolithic site of Maski. There has been much discussion on ancient India being the leading bead (both stone and glass) exporter to the world at large. Interestingly, India enjoys much the same position today.

\section{GLASS BEADS FROM INDIA}

Glass has long been the most important material for bead manufacture. This is because of its beauty, durability, versatility, and pliability. First invented in the Middle East around 2500 B.C., the earliest sample of glass is from Tell Asmar in Mesopotamia, from a stratum dated c. 2700-2600 B.C. The Indians learned the technique of bead manufacture, probably independently, around 1200 B.C. (Dubin 1987:194; Francis 1992:15; Kanungo 2001c). From more than 200 ancient Indian sites that have yielded evidence of glass, about 150 are reported to have glass beads and 36 are claimed to have been manufacturing sites. In addition to the stray evidence of glass in Bhagwanpura [Painted Grey Ware (PGW)Harappan overlap phase], Dwarka (late Harappan), and Maski (Chalcolithic), glass or glass beads are found in 29 PGW, Megalithic, and Iron Age (1200-600 B.C.) sites; 34 sites are associated with the Northern Black Polished Ware (NBPW) or in the period between 600 and 300 B.C.; 119 sites are associated with the early historic phase between 300 B.C. and A.D. 400, and particularly in the early centuries of the Christian era; 70 sites in the Early Medieval period (A.D. 400-1300); and 49 sites in the Late Medieval period (A.D. 1300-1800) (Kanungo 2002a:235).

So far the earliest evidence of glass beads in India is reported from Bhagwanpura in the Harappan-PGW overlap phase (Period I), c. 1400-1000 B.C. (Joshi 
1993 :117). In the Ganga Valley the occurrence of glass beads is associated with the PGW culture (c. 1000-600 B.c.). At Atranjikhera, glass beads are reported from a period dated to c. 1200-600 B.c. (Gaur 1983:218), and at Hastinapura they are found in Period II dated to c. 1100-800 B.C. (Lal 1954-1955: 94). In the south, at Maski, four beads are reported in the Chalcolithic level, dated to c. 800 B.C. (Thapar 1957:107) and at Arikamedu from c. 300 B.C. (Wheeler et al. 1946); in the Deccan, at Nevasa, they are found in levels dating to around 700 B.C. (Sankalia et al. 1960; Varshney et al. 1988:149). In the northwest, Taxila has revealed a number of glass beads, which indicates that Taxila may have been a sixth-century B.C. trading center (Marshall 1951).

The main centers of glass bead manufacture in ancient India include Ahichchhatra and Kausambi in north India, Arikamedu and Karaikadu in south India, and Kolhapur and Nevasa in the Deccan. Apart from these, there are a number of other states and regions that have yielded some evidence of glass bead manufacturing (Fig. 1), and some may have even been engaged in the export of beads. These include:

Andhra Pradesh: In about the second century A.D. at Kondapur, Medak district, glass beads of different varieties and different production techniques, like wirewound, mold, chevron, and gold foil beads (Dikshit 1952b), have been found. Large numbers of glass beads and iron are found in the second to third century A.D. at Puduru, Nellore district [Indian Archaeology: A Review (henceforth IAR) 1994-1995:2]. At Kadkal, molds of Vijayanagara coins were found together with glass slag near a furnace, which is believed to have been used for the manufacture of beads (Annual Report of the Archaeological Department of his Exhalted Highness the Nizam's Dominions 1936-1937:17). Deo (2000:9) reports evidence of furnace, glass slag, and glass wire at Kadkal.

Bihar: Glass beads and stone molds have been recovered from Champa, Bhagalpur district (IAR 1974-1975:9).

Delhi: Profuse amounts of green glass and beads have been found in Period II (late thirteenth or early fourteenth century A.D.) at Lalkot, Delhi (IAR 19931994:25).

Gujarat: Beads were found in large quantities in all stages of fabrication in Period I (beginning of the third century B.C.) levels at the site of Broach, Broach district (IAR 1959-1960:19).

Karnataka: Diverse materials and shapes of beads, including those of glass, were found in Period III (Iron Age) at Banahalli, Kolar district (IAR 1986-1987: 45). Glass and glass beads are found in abundance in Phase III (Andhra period) at Brahmagiri, Chitaldurg district (Wheeler 1947-1948:263).

Madhya Pradesh: A number of waste pieces and glass slag were recovered from early historic Navdatoli in west Nimar district (Deo 1971:360-361). At Sirpur, a large number of glass beads were found near crucibles containing glass batch, which was taken as an indication of a glassmaker's house being situated near the excavated area. In addition, the site yielded large quantities of glass slag and drawn wire, and numerous beads and bangles (Chaudhuri 1986:96-97; Deo 2000:11; Dikshit 1969:68). This evidence is assigned to the Kalchuri period. Tripuri was also not far behind with evidence of large numbers of beads and slag.

Maharashtra: Numerous beads and a dozen bead molds have been recovered from the Satavahana period at Bhokardan, Aurangabad district (IAR 1972-1973: 


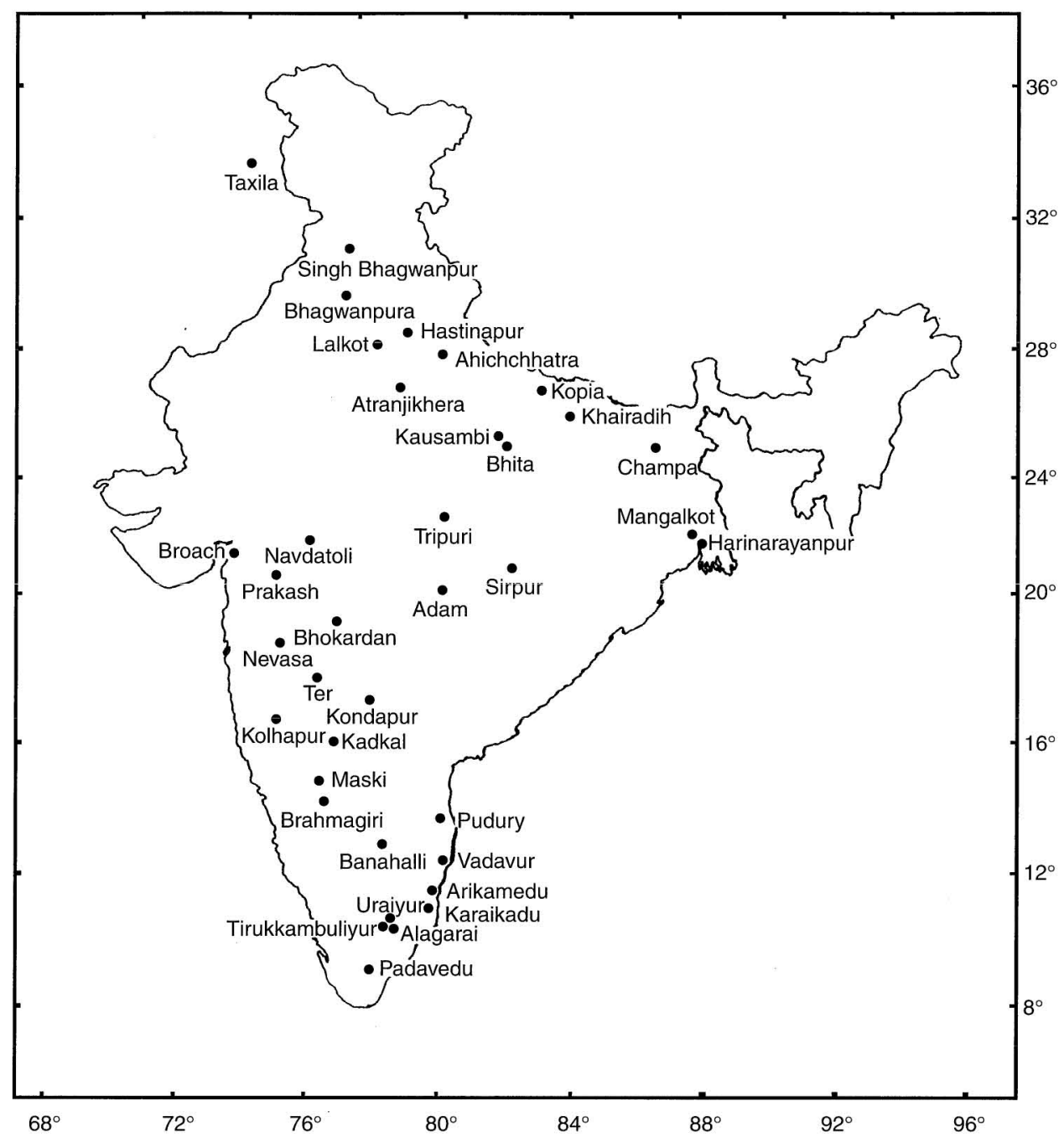

Fig. 1. Map of India showing the sites claimed to be glass bead production centers.

20-21). From post-Satavahana and Early Medieval periods (third to twelfth centuries A.D.), large amounts of glass slag and vitrified glass fragments were found (Verma 1974:201). The glass slag and large numbers of unfinished beads in various stages of manufacture, indicate with a great degree of certainty that glass was actually manufactured at Brahmapuri, Kolhapur district (Sankalia and Dikshit 1952 :98). Numerous glass beads and a few bead polishers were unearthed from Period V (150 B.C.-A.D. 200), at Adam, Nagpur district (IAR 1989-1990:65, 1990-1991:50). Some unfinished specimens in various stages of bead production have been recorded at Prakash (Early Historic level), Dhulia district (Thapar et al. 1964-1965:110-111). At Nevasa, glass beads constitute nearly one-fifth of the 
total aggregate of beads. Besides the use of colored glass, these beads represent various techniques of glass and bead manufacture. Glass beads are restricted mostly to Period V (Indo-Roman) and a few are from Period IV (Early Historic) and VI (Muslim-Maratha). The stratigraphic yield of glass objects shows that although glass was known in Period IV, it developed as a cottage industry only in Period VI. This must have been due to the arrival of new cultural forces (Deo 1960).

Pondicherry: At Arikamedu, a plethora of beads was found; a number of these were unfinished (Wheeler et al. 1946:95-97). In later years, various scholars have written about the beads from Arikamedu (Francis 1987, 1990b, 1991, 2002, n.d.; Stern 1987a, 1991).

Punjab: In Period I (700-400 B.c.) at Singh Bhagwanpur, Rupnagar district, glass was used for beads and bangles (IAR 1980-1981:51).

Tamil Nadu: Innovative shapes of glass and paste beads are reported from Period II (first century A.D.) at Alagarai, Tiruchchirappalli district (IAR 1963-1964: 21). There is evidence for half-finished beads from Tirukkampuliyur and Uraiyur in the Tiruchirapalli district of Tamil Nadu (Gururaja Rao 1970:265). Beads in various stages of manufacture and crucibles of stone are found in association with Early Medieval cultural assemblages at Vadavur, Chingelput district (IAR 19791980:68). At Karaikadu, North Arcot district, large numbers of finished and unfinished glass beads, raw materials used in the manufacturing process, as well as vitreous slag of amorphous shapes were found in association with Rouletted Ware (IAR 1988-1989:80; Ramachandran 1980:111-112). At Padavedu, Tiruvannamalai district, blowpipes and crucibles were found in levels dated to the thirteenth and fourteenth centuries A.D. (IAR 1993-1994:98).

Uttar Pradesh: Khairadih, in eastern Uttar Pradesh, has yielded evidence of finished and unfinished varieties of red glass, slag pieces, and cane from Period II (700-200 B.C.); it is reported to have been a local glass bead industry center (IAR 1981-1982:68). Also reported are microbeads of blue glass from Period I (1100700 в.с.) (IAR 1982-1983:93). The site of Kopia, Basti district, dated to the fifth century B.C., has yielded innumerable glass beads, thousands of glass fragments, fragments of clay crucibles with glass sticking to them (glass was melted in them), big pieces of glass, and lumps of unworked glass (Abdurazakov 1987:38; Dikshit 1969:39; Lal 1987:45; Roy and Varshney 1953; Sen and Chaudhuri 1985:6465). Numerous beads are found in the Gupta levels at Bhita, Allahabad district (Marshall 1915:94).

West Bengal: Several unfinished and finished beads of both stone and glass are found in Period V (Gupta) levels at Mangalkot, Burdwan district (IAR 19871988:114) and at Harinarayanpur, 24 Pargana district (Singh 1983 : 154).

Glass (kāca) beads are first mentioned in early Sanskrit and Buddhist literature. Mukharji (1888), Ghosh (1924), Chaudhuri (1986), Dikshit (1964-1965, 1969), and Deo (1987) list a few of them; for instance in the Yajurveda (c. 1200 B.c.), $k \bar{a} c a$ is mentioned as female ornaments which were made by means of stringing with gold thread. In Śatapatha Brahmana (c. 1000 B.c.), the word kāca refers to glass beads that were used for decorating horses for the Aśvamedha sacrifice. There are also references to women wearing glass beads and to the wearing of or threading of 101 beads of glass. The Taittiriya Brahmana also refers to the wearing of glass (beads). In the Sutra period, one comes across references to glass beads in the Baudhayana Srauta Sutra and in the Manava Srauta Sutra. Glass is also 
mentioned in the Mahabharata, and in the Yuktikarata, the effects on the human digestive system of drinking water out of a glass tumbler are stated to be the same as those from drinking out of a crystal cup. The Ramayana refers to the makers of glass, the kachakara. Kautilya's Arthaśāstra (third century B.C.) alludes to glassmaking in two places: (1) Adhikarana 14, Adhyaya 1, Sutra 12, cites that in order to punish the enemy, obstacles like the smoke of puti, karanja leaves ... as in the manufacture of glass, by burning cow dung, etc., should deliberately be created; (2) another passage Adhikarana 2, Adhyaya 14, Sutra 45, though somewhat corrupt, is interpreted to be the process of making gold-foiled glass beads. It describes the piercing of glass beads in a molten stage for the purpose of setting glass fragments (kśepana) in gold ornaments for the preparation of so-called glass gems. Among the various punishments inflicted for stealing, it was ordained that a person stealing articles made of copper, bronze, tin, glass, or ivory was to be fined 46-96 panas. The Māhavagga section of the Vinayapitaka (Buddhist period) alludes to the use of shoes ornamented with glass as being forbidden to the Buddhist bhiksus. The Chullavagga similarly forbids the use of glass bowls. In Puranas (c. fourth to fourteenth centuries A.D.), some texts like the Matsya, the Vishnu, the Bhagawata, etc., assigned to the Gupta period, refer to kāca (beads). Apart from these, references to glass vessels for preserving medicines can be seen in texts like the Charaka and Śusruta Samhita. In the Amarakosa (c. seventh century A.D.), mention of glass vessels, cups, and dishes are made. The Brihatsamhita (c. sixth century A.D.) also mentions glass, and there is mention of spectacles in the Vyasoyogi Carita by Somnath Kavi (1446-1539 A.D.).

One of the earliest literary references to glass or quartz is a Tamil word, palingu, used in the Manimekalai $(3,64)$, possibly a corruption of the Sanskrit word sphatika, though the prakrit phalika (quartz) occurs in the Bhattiproru inscription in the second century B.C. (Srinivasan and Banerjee 1953:113).

Foreign travel accounts of Pliny (translated by Bostock and Riley 1857), Periplus (translated by Schoff 1912), and Strabo (Majumdar 1960:279, 394) consider Indian glass to be of high quality because it was made of pounded quartz.

In spite of numerous references to glass objects and beads both in ancient literary and archaeological records, there is precious little to be found in them regarding the people, techniques, tools, furnaces, and trading of the product involved. No excavation reports of Indian sites yielding glass beads have discussed the manufacturing techniques involved. A few have hinted that the recovered beads were produced by winding on a wire, but the basis has not been indicated by them (Deo 1971:361; Dikshit 1952a:98, 1952c:53; Thapar et al. 1964-1965: 110-111). However, a study of the morphology of ancient glass beads and their debitage reveal the probable method used to produce the beads. This aspect of glass bead technology is very important because all known traditional production techniques require different technological strategies. These are unique and leave distinct debitage. The discovery of glass tubes with spherical and other shapes of glass beads at an archaeological site may not necessarily mean that it is a glass bead production center. However, the discovery of microbeads (Indo-Pacific) with perforated and unperforated glass tubes of different lengths along with other waste material probably indicates that it is an Indo-Pacific glass bead manufacturing center (Kanungo 2001a, 2001c; Francis 1990b; Stern 1991). A highly developed and complex furnace is required for Indo-Pacific beads, whereas small hearth-like 
furnaces or comparatively large 14-20-seater furnaces are made for furnace winding; no furnace is required for lamp winding.

Most of the beads found at archaeological sites in the Indian subcontinent seem to be produced using drawing, scooping, winding, and molding or a combination of these techniques. As far as traditional production methodologies are concerned, there are two present-day major glass bead industrial centers in India, which not only produce beads using traditional techniques, but also export them. These are at Papanaidupet (drawing method) and Purdalpur/Purdalnagar (furnace-winding and manual pulling-drawing method). Banaras Beads Limited (henceforth BBL) and its associated villages have produced glass beads using the lamp-winding technique since the 1950s for export all over the world (for details see Kanungo 2001c). Except for the complex drawing technique involved in Indo-Pacific bead manufacture, other techniques have not been given due importance in the available literature (Francis 1990a, 1990b, 1991, 1994, 2002; Gupta 1999, 2000; Kanungo 2001a, 2002a; Stern 1987b, 1991).

Glass has long been the most important of bead materials. Technically, glass beads are produced by heating raw glass above its melting point and allowing them to cool without crystallizing. There are many ways to manipulate a bit of glass into a bead. Over the centuries, glassworkers have tried almost every imaginable technique to make beads. Some of them, such as winding and drawing, became the standard in many places.

\section{THE WINDING TECHNIQUE}

Glass is a "super-cooled liquid." The major ingredient in most glass is silica, which requires very high temperatures to melt. It cools and hardens very fast. This leaves a very short span of time for the craftsman to shape it. However, since ancient times, artists have found ways to exercise their creative will in designing and shaping glass into beads. The furnace-winding technique is regarded as the oldest, simplest, and most common method of beadmaking (Basa 1993:93; Francis 1992: 15; Kock and Sode 1995 :24; Sleen 1973:23).

Different methods of manufacturing beads have been discussed (Basa 1993; Francis 1983, 2002; Kanungo 2001a, 2001c; Lamb 1965; Lugay 1974; Sleen 1973). From the second century B.C. onward, glass beads were made at different places throughout India, using indigenous techniques (Basa 1993). One of the most important and surviving glass bead production techniques in India is the furnace-winding technique. In this technique, glass beads are produced by twisting glass around a metal rod, the mandrel or pontil. The beads produced by this method are commonly known as wound beads.

These beads have traditionally been used for the harnesses of donkeys, cattle, horses, camels, and elephants (Fig. 2). As well as having a decorative effect, these beads have been attributed with strong protective powers, warding off the "evil eye" (Kock and Sode 1995:24). Glass beads have also become part and parcel of life in many tribal communities (Kanungo 2000, 2001a, 2001b, 2001c, 2002a, $2002 b$ ). Such use is probably one of the important reasons that the craft of glass beadmaking has survived to the present day. The belief is so strong that $\mathrm{I}$, a native of Orissa, remember in my childhood putting black wound beads around my family's cows and crossing nude over a cow seven times whenever the cow ap- 


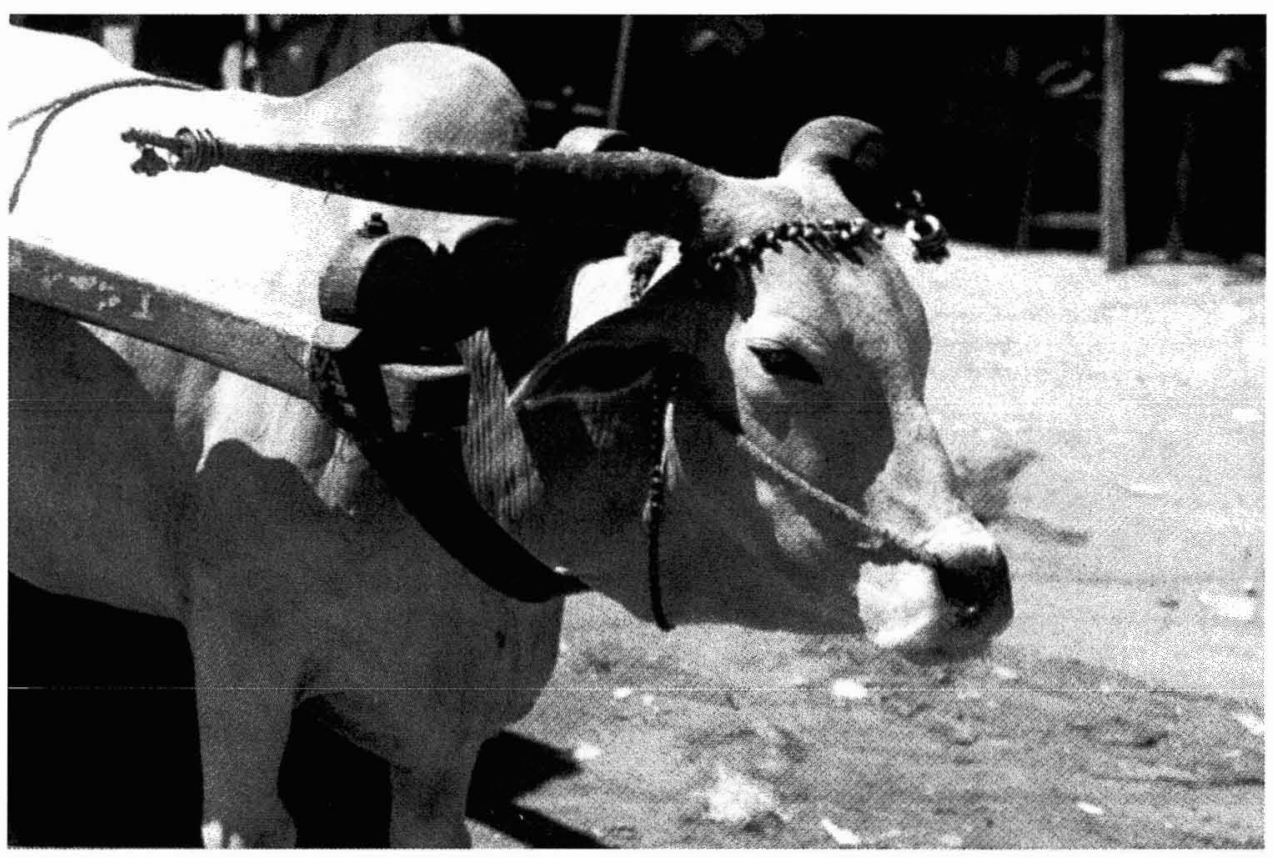

Fig. 2. A cow with wound beads at Papanaidupet (the center of Indo-Pacific drawn-bead production), Andhra Pradesh.

peared to be ill and unable to stand up. Such practices are widely prevalent, even today.

Of the several ways to wind beads, two are common in India: one is lamp winding, widely used in and around Varanasi and Purdalpur, and the second is furnace winding, used at Purdalpur. However, all wound beads share one characteristic: the fabric of the glass, including any additives or residues, is oriented around the perforation. In other words, striation marks can be seen around the perforation in such beads (Fig. 3). Very often differently designed molds are used to give various shapes to the bead. These techniques are discussed below.

\section{Lamp Winding}

Glass is transformed into rods or sticks, which are called canes. Workers melt them at a small heat source, traditionally a lamp (hence the name). The glass is then wound around a wire or a thin mandrel. While the glass is still hot, the bead may be shaped or given decoration using glass canes of other colors. These beads can be annealed in the lamp flame. Once cooled, beads are knocked down (for details see Kanungo 2001c). This is alternatively known as the blow-lamp technique and was introduced in Varanasi in 1938 when a Czech couple, the Henricks, established glass bead training in Banaras Hindu University (Kock and Sode 1995 : 27). Ethnographically, we find that beads are produced using this technique in many parts of the world. They are Italy (Venice), the Czech Republic (Bohemia), Germany (New Gablonz), India (Varanasi), China (various places), Indonesia (Jombang), France, and the USA (Francis 1992:15). 


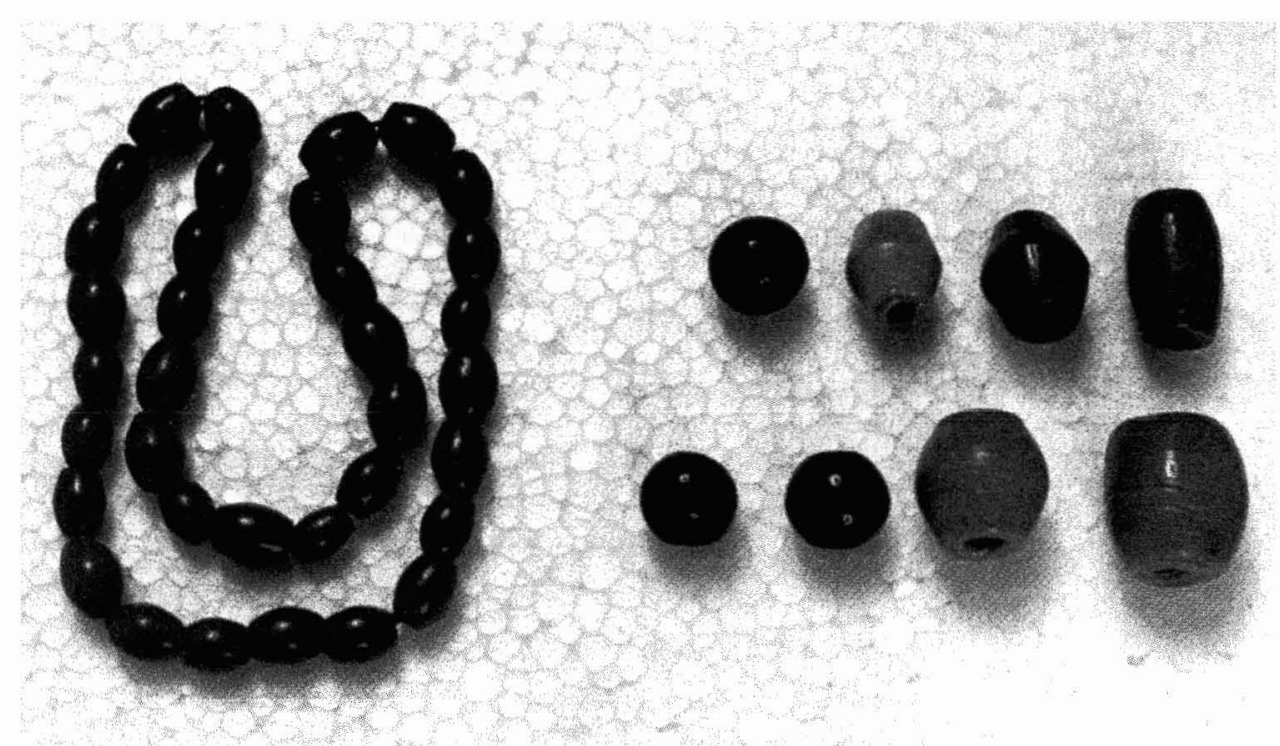

Fig. 3. Wound beads showing striation marks (the string was found among the Juangs, a tribal community residing in the State of Orissa, and individual beads are from the private collection of Dr. Arati Deshpande-Mukherjee, Deccan College, Pune).

\section{Furnace Winding}

Glass is heated in a crucible in the furnace. An iron rod (mandrel) is dipped into the glass, and while being taken out, with a dexterous twist, the glass bead is built up (Fig. 4). While still hot, it may be shaped with paddles and other tools or other glass may be added for decoration. Traditionally, beads are produced following this technique at various places around the world, such as China (various places), the Middle East (Hebron, Gorece, Bida), Turkey, Egypt (Cairo), Uzbekistan, Afghanistan, India (Purdalpur), Pakistan (Hyderabad), and Nigeria (Francis 1992: 15).

Distinguishing the beads produced by these two techniques is not easy. However, the internal features in wound beads can provide important clues. A black film of iron oxide from the mandrel is often left behind when a bead is furnacewound. A powdery deposit may be left when a bead is lamp-wound because the operation requires a separator on the wire to remove the finished bead. Currently, however, these deposits are often removed using various chemicals.

\section{Molded Beads}

Wound beads can be pressed or spun in a half-mold to give them a special shape, but true molding was a development of the Bohemians (or Czechs) in northern Czechoslovakia (Francis 1992:17). The original molds were hand-held tongs into which a bit of hot glass from a cane was placed. In ancient Indian molded glass beads, usually a very thin rim is seen. This is caused when the mold is joined and the flow of excess glass creates a thin circumference around the piece. Alternatively, it is caused by differential cooling of the glass in the upper and lower faces 


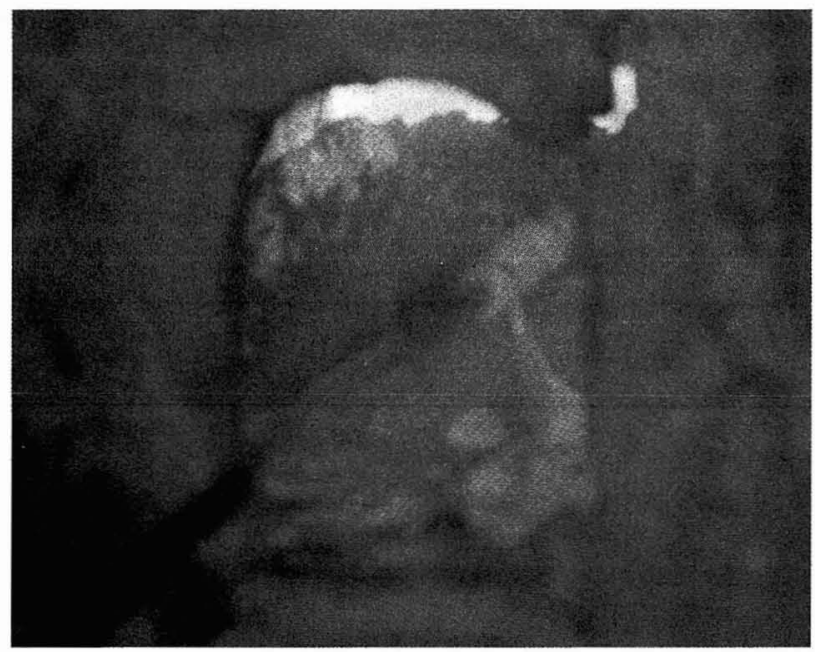

Fig. 4. A furnace-wound bead being built up.

of the mold. This is known as flash. In the recent past, such marks were successfully removed by polishing the beads in a rotating drum with carborundum powder.

\section{PURDALPUR: THE CENTER OF FURNACE-WOUND BEADS}

The village of Purdalpur is also known as Purdalnagar on recent maps. It is located in the Sikandaragaon Tehsil of Hathras district, Uttar Pradesh. The entire village's economy is based on glasswork, particularly that of glass beads and bangles. Almost all of the people are engaged in one way or another in the bead production cycle. The men of the village either work on the bead furnace or in activities related to the bead industry, as glass shop owners, in glazing furnaces, or making furnaces. The women clean and string beads. The people who are not engaged in this furnace-bead cycle are engaged in lamp-bead production. There are a few agricultural cultivators, but, on their return from the fields, they cut and collect the brushwood in their ox-carts every day for the beadmakers and the women make cow-dung cakes for fuel. Clusters of beautiful cow-dung stores in the form of houses are located in the village (Fig. 5). The smiths and the metal casters make molding tools, mandrels, blow lamps, air nozzles, and spring molds. Girls and their mothers can be found cleaning and stringing the large quantities of beads.

The roads in the region are busy with the transportation of glass, glass beads, and bangles, either on heads or on cycles or on overloaded carts pulled by a camel. The size of the load is as much a result of voluminous and careful packing as it is of the glass material. One can also see carts full of brushwood or cow-dung cakes being transported. The state buses going to and from Purdalpur always carry several packets of glass, glass beads, and bangles. All of the small nullahs crossing the village roads are full of bead debitage. The entire village and the surrounding area is littered with glass bead debitage. 


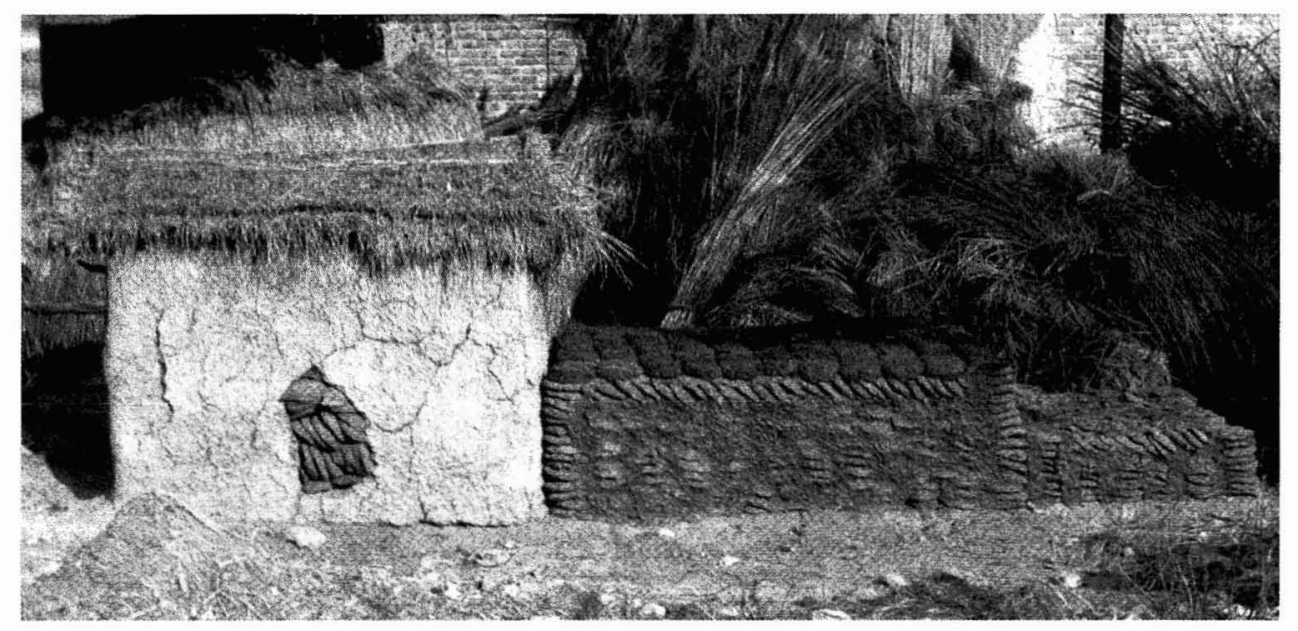

Fig. 5. Cow dung stored in house form.

\section{FURNACE-WOUND GLASS BEADS}

The beads are made with ductile glass wound upon a mandrel and rolled upon a form-iron. The mandrel is a piece of round steel about a meter long with a conical end. The form-iron is an oblong piece of iron plate that is used to forge the bead into its final shape. The wound material is given shape by rolling it forward and backward on a smooth metallic surface (usually a piece of old well-worn railway girder) with the mandrel as an axis. The bead is shaped with frequent use of a form-iron or by rolling it in a single or multichanneled trough. While still hot, it may be designed variously with paddles, form-irons, and other tools (Fig. 6). A wound bead can be reinserted in the furnace when it is still hot and striped or coated with another colored glass with the aid of a second mandrel. Two colors can be maintained in one crucible as glass in these crucibles is not allowed to become liquid. To make beads of some special pattern, shape, or edged form, various open molds or double spring-molds are used (Fig. 7). Several such wound beads are built on a single mandrel.

When the bead is finished, the mandrel is stroked hard with an iron tool called the mala so that the hole gets a little bigger and the bead is knocked off during the brief period when the iron cools and contracts faster than the glass. The hole is left when the mandrel is removed. The perforation circumference of the resultant bead will vary according to the tapering end of the mandrel. The bead is allowed to slide down into a small clay pot, placed immediately below the working port and functions as an annealing pot (Fig. 8). When the pot is full, it is covered with hot ash from the furnace and placed in sunlight (if available) and allowed to cool slowly (Fig. 9). This is necessary to prevent stresses and cracks from appearing in the bead. One still finds plenty of cracked beads and bangles around the furnace area and village (Fig. 10). However, in most cases, glassworkers put the cracked beads and bangles back into the furnace for remelting and it is the duty of children to collect such debitage and sort it according to color. But this remelting does not result in a symmetrical color. Even when the bead or bangle is to be 


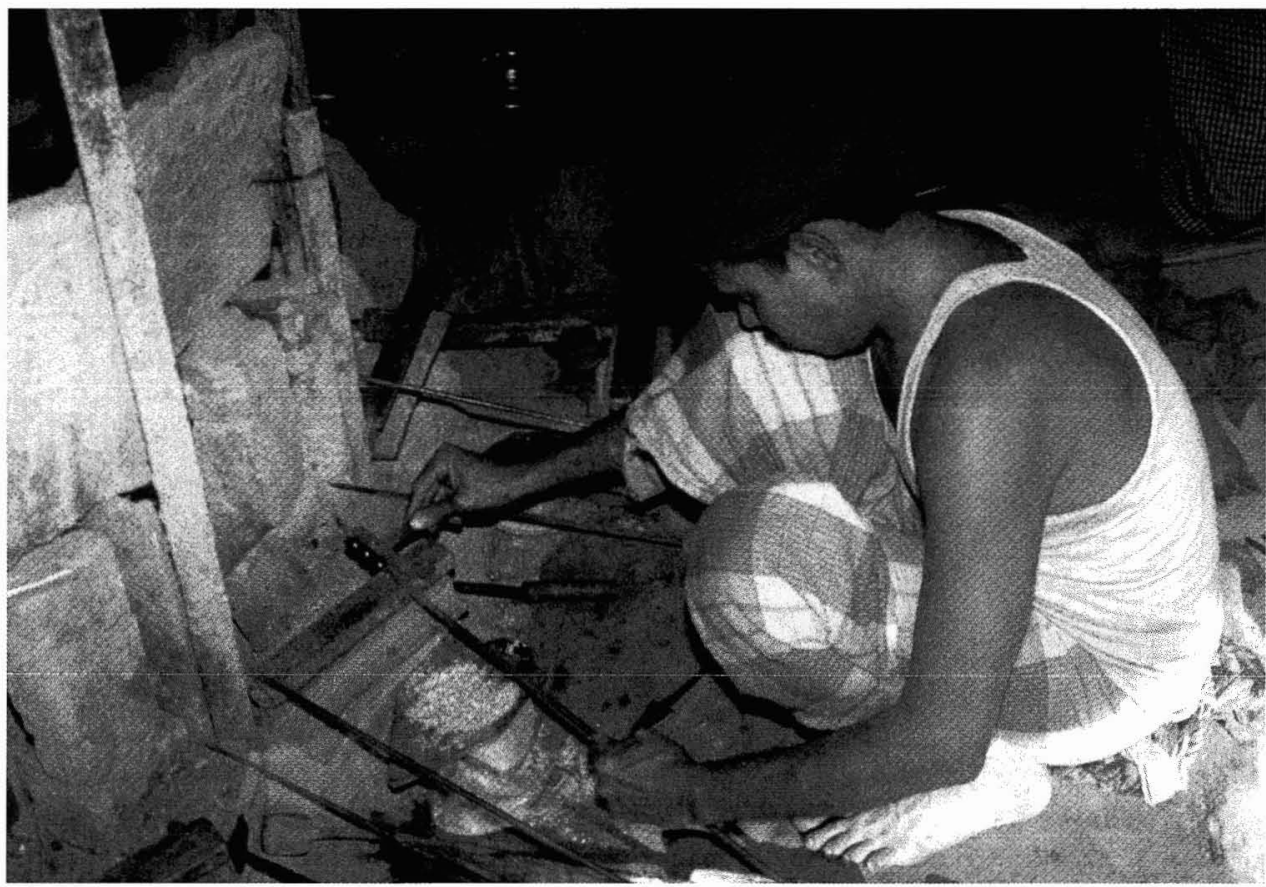

Fig. 6. Shaping the winds.

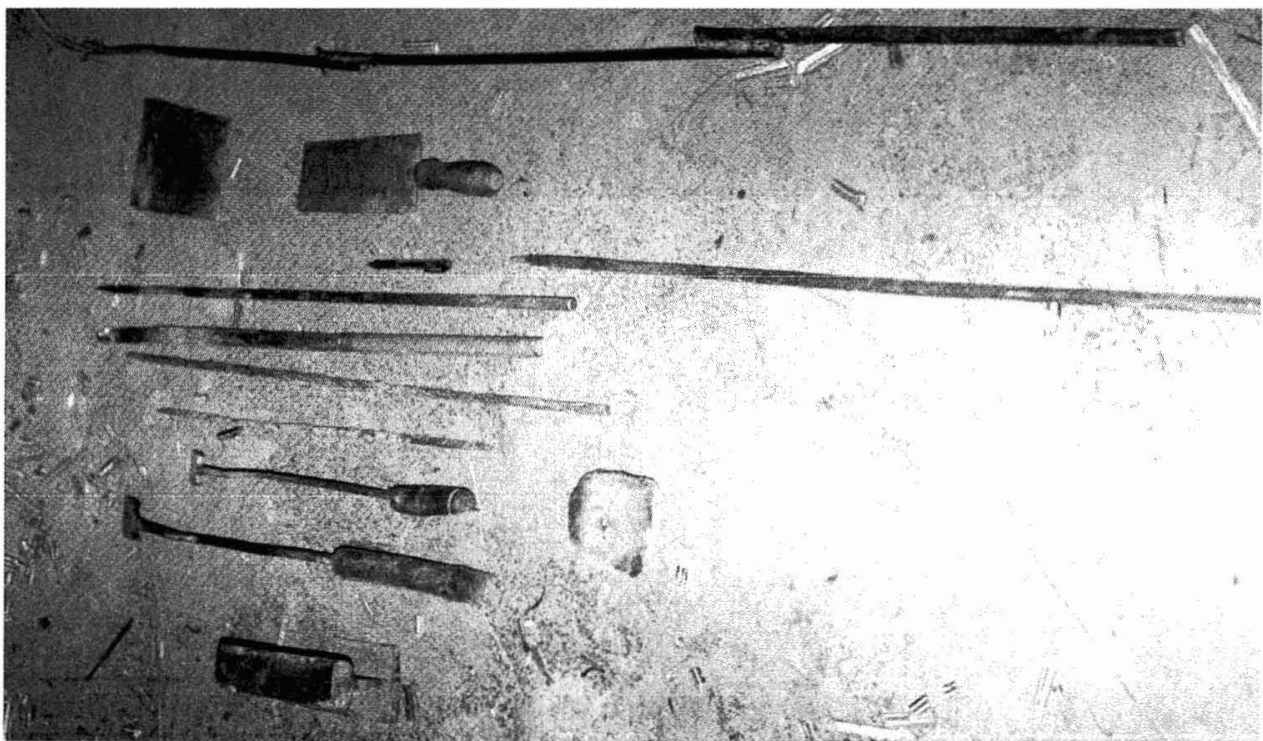

Fig. 7. Some tools used by beadmakers. 


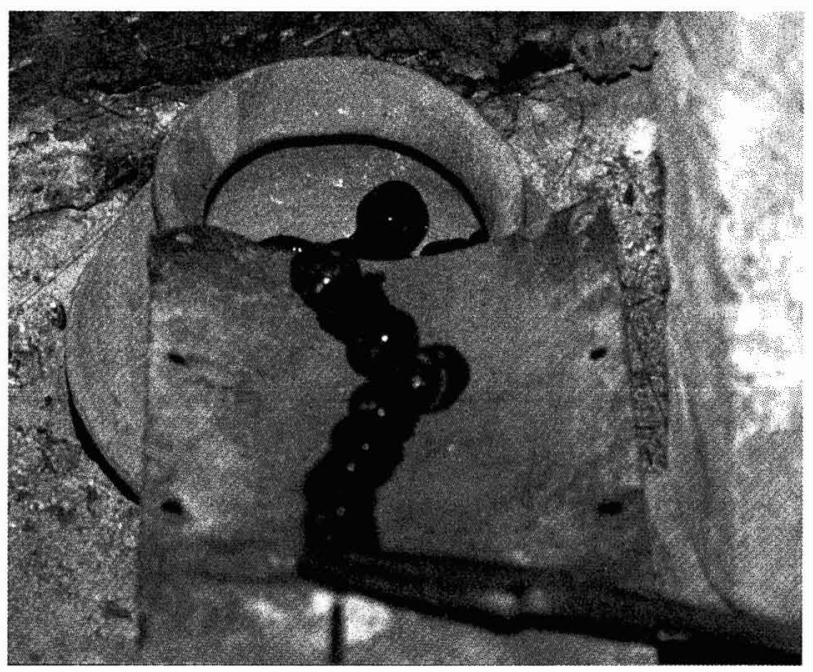

Fig. 8. Sliding beads into the annealing pot.

embellished with multicolored glass and other design material, like gold or silver foil or different colored glass powder, it is generally not remelted unless a mixture is what is desired. This leads to the accumulation of such debitage in much more quantity. On average, $50 \mathrm{~g}$ in $1 \mathrm{~kg}$ of beads comes out as debitage at the furnace.

\section{Decorating}

The initial wound beads are usually monochrome and opaque. It has been a common practice to decorate the beads with applied threads or eye motifs. The socalled "powder-glass" decorated beads are wound beads, usually black, with a

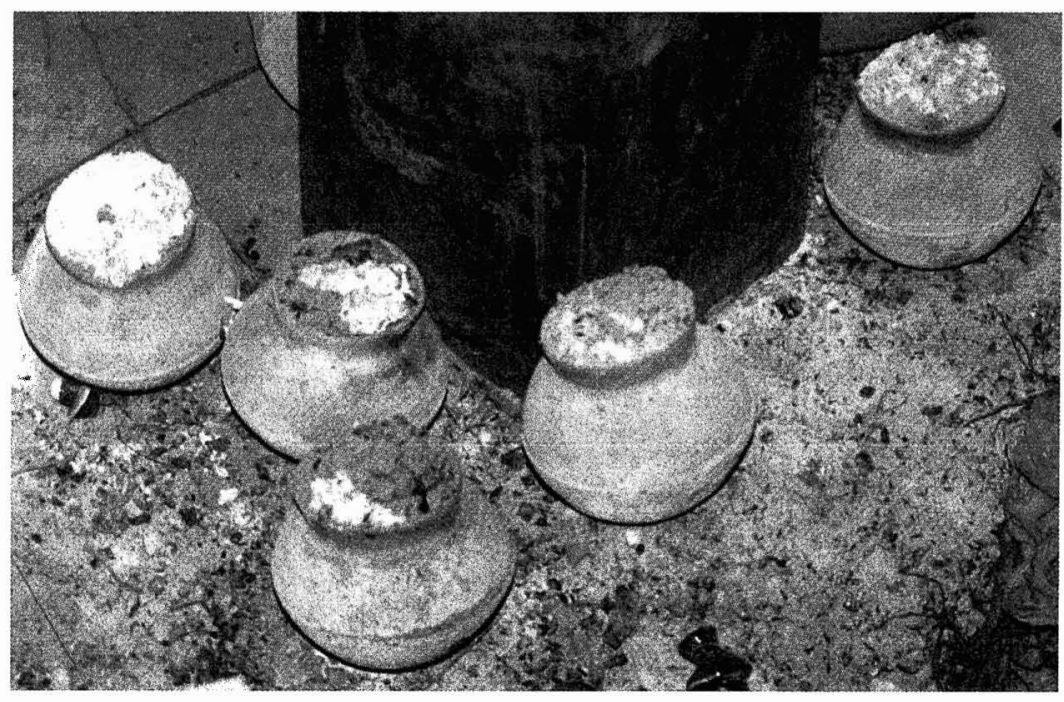

Fig. 9. Pot full of beads covered with ash. 


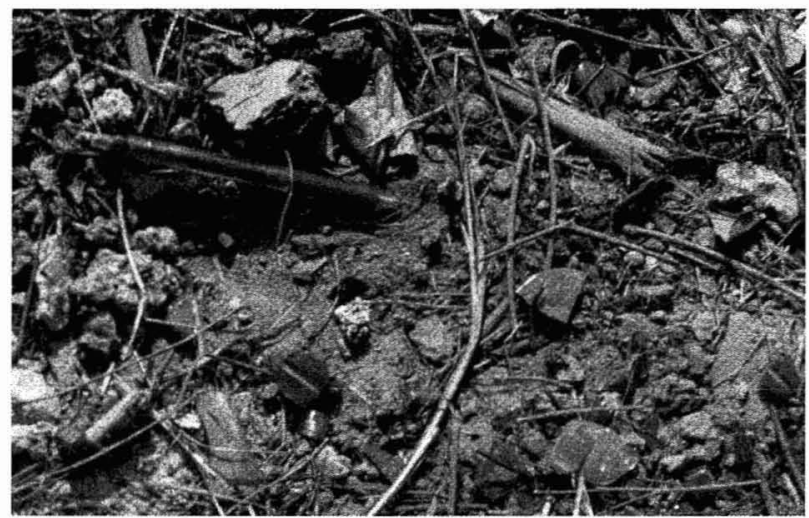

Fig. 10. Cracked beads lying scattered as debitage next to the furnace.

pattern of powdered glass melted into the surface. This is an Indian decorative technique that has been used since ancient times. The pattern on an engraved iron plate is filled with fine powdered glass, after which the hot bead is rolled over the pattern so that the glass powder sticks to it. The glass is then heated, and the bead is finally molded with a form-iron.

Another ancient form of decoration involves rolling the hot bead in either small colored particles or crushed glass or in colored and twisted glass threads. With this method, the desired pieces of glass are placed for heating on an iron plate positioned just in front of the working port. After the bead has been rolled in the colored glass, it is heated so that the attached glass melts into the bead (Fig. 11). The bead is given its final shape with a form-iron. For an inner filling, the hot wound glass is rolled over some other colored glass powder and then given another coat of transparent glass.

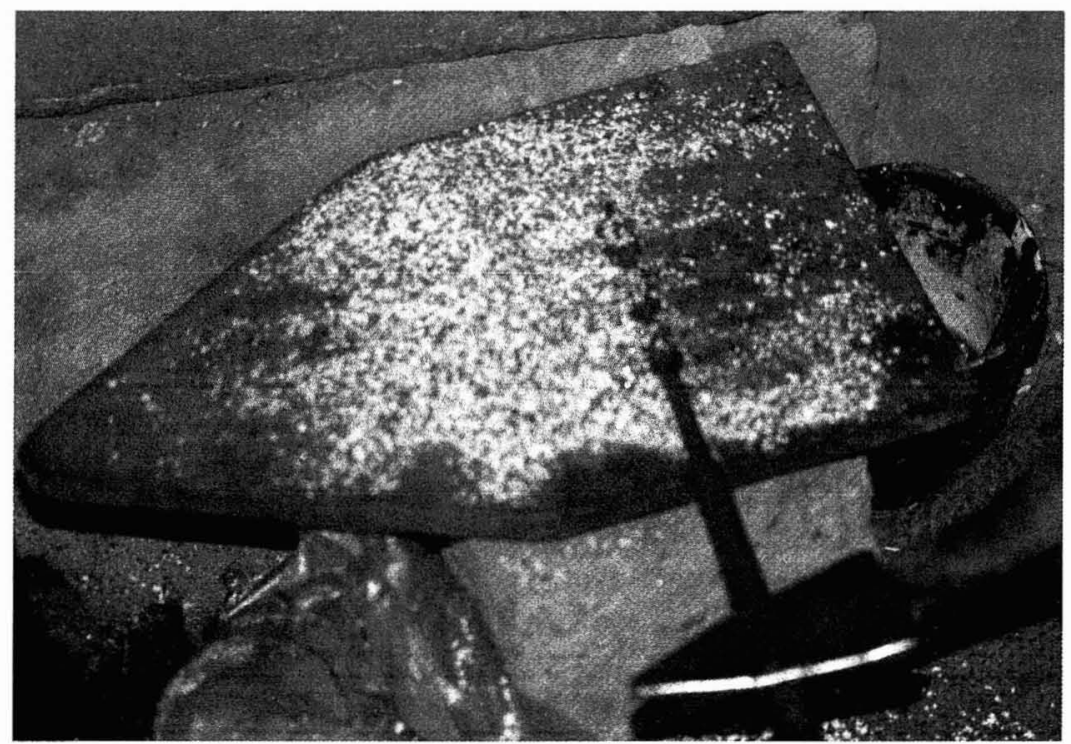

Fig. 11. Appliqueing the hot winds with different colored glass powder. 


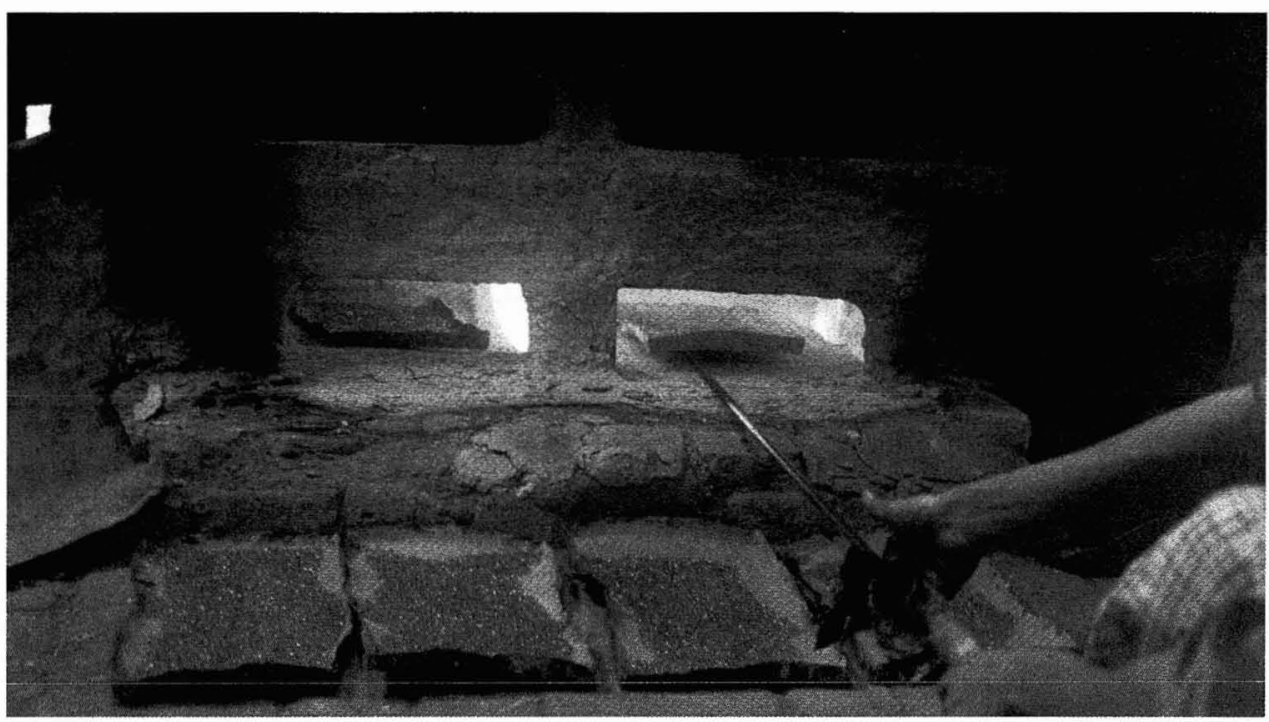

Fig. 12. Glazing furnace.

In the towns and country areas around Purdalpur there are several workshops specializing in silk-printing decoration on beads. Other companies stain or treat the surface of the beads chemically in a different way. By heating the glass beads in small furnaces, and applying a thin layer of metallic oxide, the beads are given a metallic appearance. Some workshops treat the glass beads so that they obtain a mother-of-pearl-like glow, and thus come to resemble true pearl (Kock and Sode 1995:26). Treatment with hydrofluoric acid gives the beads a matte surface. The furnace used for this metallic look is generally made of furnace bricks, clay bricks, and clay. The furnace looks like a four-shelved cupboard (two on each side). The walls are made of furnace bricks but the roof is made of clay, and the channel to feed fuel and remove the ash is made of furnace and clay bricks (Fig. 12). The roof needs to be repaired every 20 days. Beads are placed inside these shelves, spread in a clay-lined tin tray for about 15 minutes and then treated chemically for the appearance. The trays are placed in and removed from the furnace with the help of a long handled drawing tool made of iron. At all these "fancifying" workshops, one sees the rejects: broken and other imperfect beads.

\section{Bangles}

Here I describe the technology involved in the production of only those glass bangles which are produced from wound glass. The bangle makers first wind a larger amount of glass on a mandrel made for beads, and then follow the same process as that for beads, the only exception is that while making the bangle they rotate the mandrel, keeping an iron wire between the wound glass and the mandrel (Fig. 13). This results in a larger perforation and, when it is still hot, the worker, with lightning speed, puts the wound glass on an arm-ring cone (kalgood) which is attached with a meter-long iron rod. This is also rotated like a mandrel 


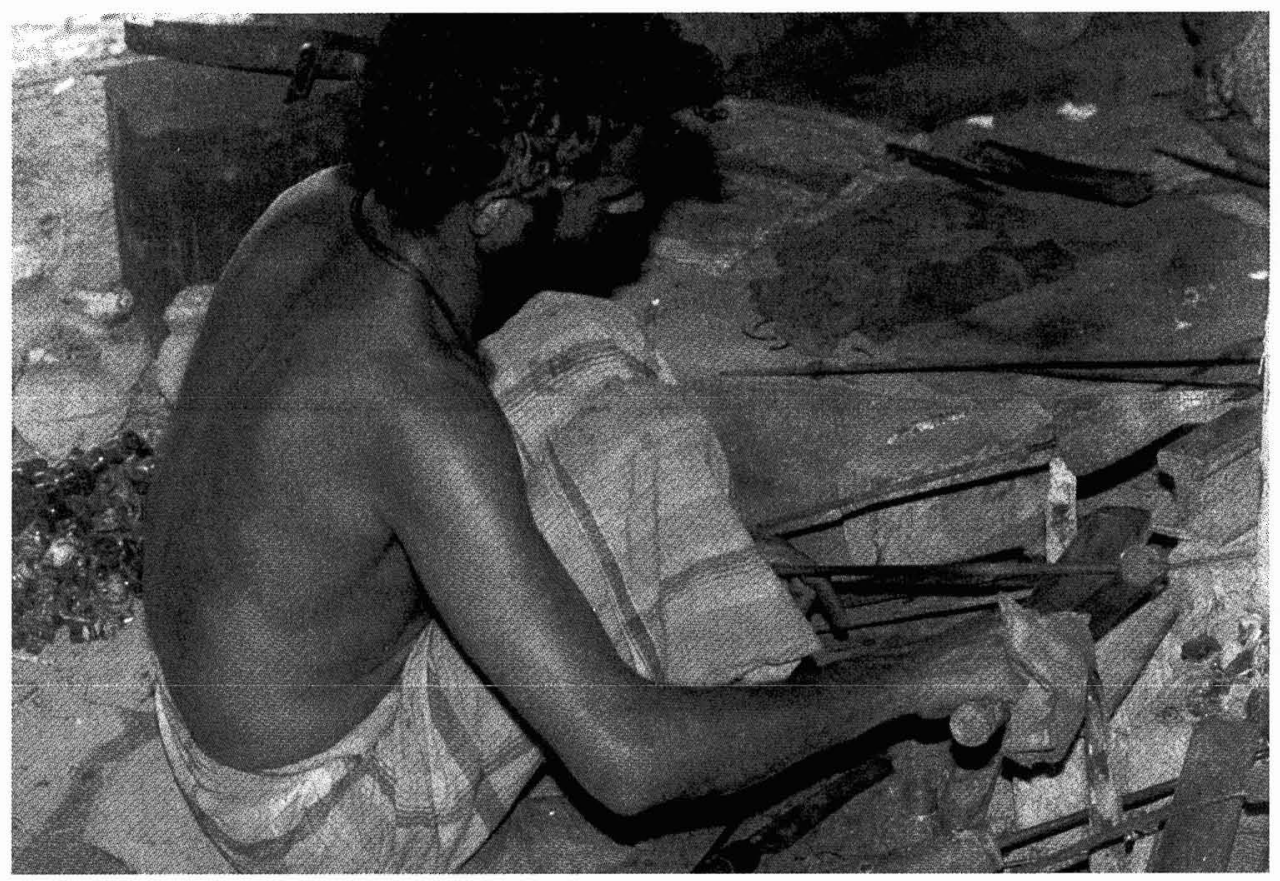

Fig. 13. A big piece of wound glass is drawn for a bangle.

using his open palm held against the handle to facilitate backwards and forward movement on the girder. The cone is held upward in a slanting position toward the opening of the furnace, and throughout the process the iron wire is maintained between the cone and the glass wound ring. This permits gradual enlargement of the wound glass from the tip of the cone. The wound glass is allowed to slip down to the broad base of the cone until the requisite size of either bracelet or bangle is achieved (Fig. 14). The arm-ring cone is made of clay and is rough on its surface. It has a number of grooves over it for size control. For making bracelets, a single-channeled trough is used. Colored glass can also be applied to the bangles.

\section{The Furnace}

At Purdalpur one sees a profusion of furnaces right from the entrance to the village. In contrast to the general opinion that glasswork areas are placed on the outskirts of habitation areas because they generate enormous temperatures and smoke, at Purdalpur they are occasionally located inside the habitation area. However, in most cases they are a little away from the habitation area. At present there exist about 200 furnaces where the beadmakers produce various forms of glass beads, bangles, and many other small objects like Mahadev (Shiv-linga). All beadmakers are male and the majority of them are Muslim (Kock and Sode 1995 : 17). There are normally 14 to 20 beadmakers working in each of the glassworks. Each furnace house has one furnace inside, and a small clay and brick locker in one corner for the safekeeping of tools and glass cakes. Almost all of the 


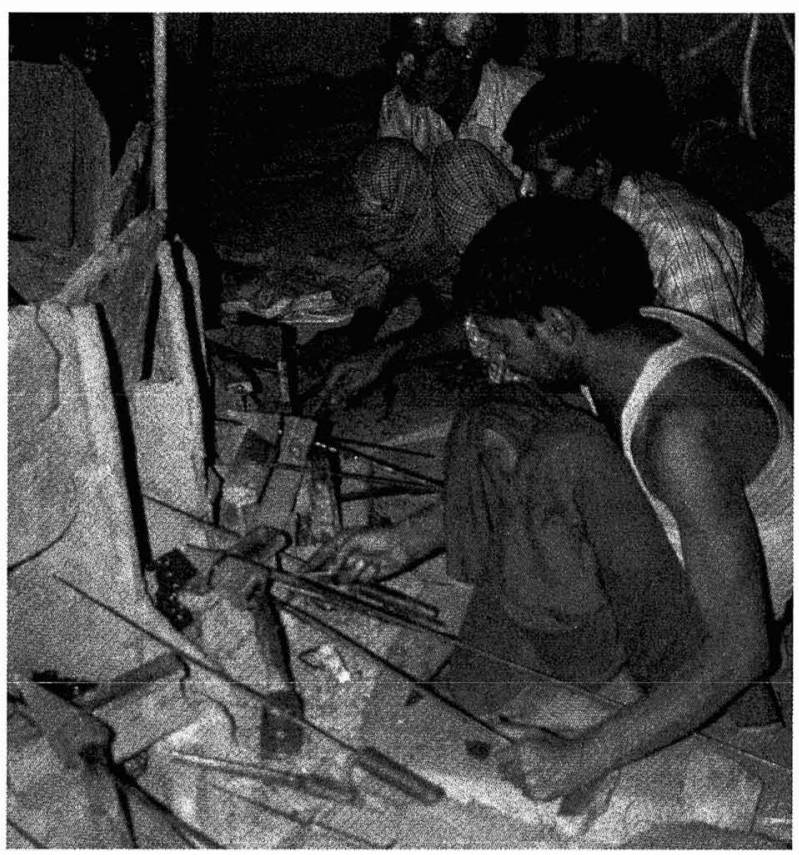

Fig. 14. Bangle being formed on an arm-ring cone.

furnaces have a thatched roof, which is high in the center and has low margins at the two sides supported on six to eight brick or wooden pillars. The bigger tools, like the drawing iron, arm-ring cone, mandrel, grabbing iron, stirring iron, glassmaker's pipe, etc., are left inside this open house after the day's work without any fear of theft (Figs. 15, 16).

At the furnace, each glassworker has his own place of work, where he sits on the ground or on a sack while he works. Many of the workers have achieved mastery over a variety of differently designed beads while a few specialize only in making particular types of beads, bracelets, or bangles.

The beadmakers construct their own furnace. This job is led by one of the experienced beadmakers and takes about a week. However, there are certain young professionals in the village who have mastered the art of furnace making. A number of rectangular, sun-dried clay plates are placed upright around the pit that is to serve as the base of the fire chamber. These plates separate the individual work stations. The number of plates shows how many beadmakers can work around the finished furnace. The circumference of the furnace is bounded with a line of clay bricks at ground level. A clay dome is made either by directly building over the clay plates, or separately built in an inverted stone or cement basin (in which the animals are fed), and placed laterally over the standing clay plates. In any case, the top is left open and is covered with a clay plate only when the furnace is in use (Fig. 17). This opening facilitates a regular change of crucibles. The furnace is built of coarsely tempered clay mixed with chopped straw. This practice of adding fine chopped straw to strengthen the "poor," "lean," or sandy clay is an ancient technique (Singh 1989:187). When the furnace is fired, the straw burns off, 


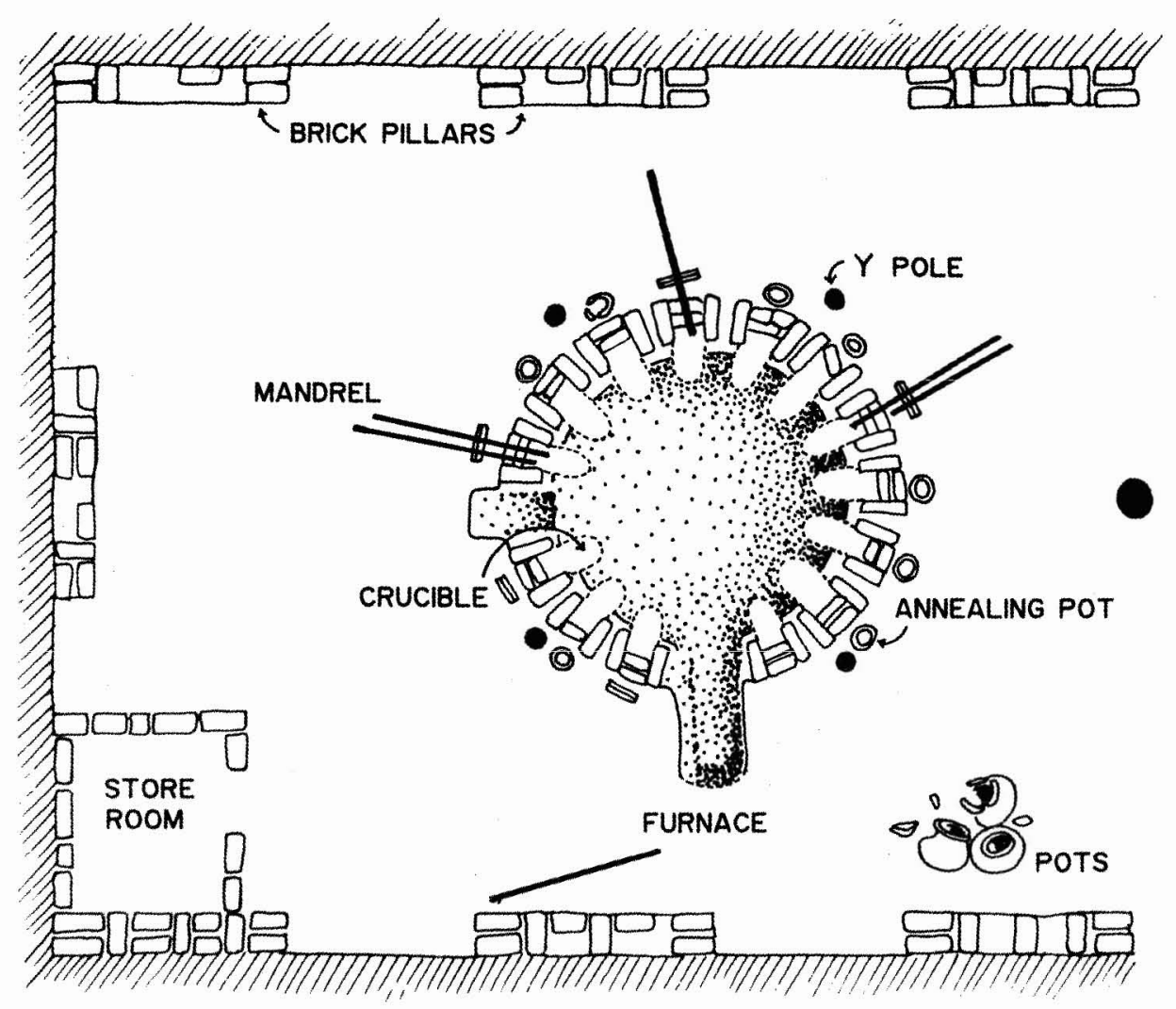

Fig. 15. Ground plan of a beadmaking furnace.

leaving a highly porous clay furnace that can cope with the great range of temperatures between the day's high working temperature and the night's cooling off. Outside every furnace house, clay is stored in a pit and every day one of the workers tramples on it while pouring water. Four Y-shaped wooden poles are placed close to the furnace in a square layout to dry the wood for the next day's fuel.

The furnace is made in such a way that the various types and forms of beads, bangles, and other minor objects can be made at each workstation. The opening from which the glass is picked up is called the window, and just inside it there is a small open crucible for the glass, measuring about 25 -by-40 $\mathrm{cm}$ and made of clay mixed with chopped straw. The windows are uniquely designed for various products like beads, bangles, and other objects. It is also necessary to change the crucibles continually, because a crucible will normally burn out after about two weeks (Fig. 18). When crucibles are replaced or the structure is repaired, the outside of the old furnace is built on with new, straw-tempered clay. The logical construction of the furnace is derived from the experience of generations, transmitted from father to son over thousands of years. With this type of furnace, one 


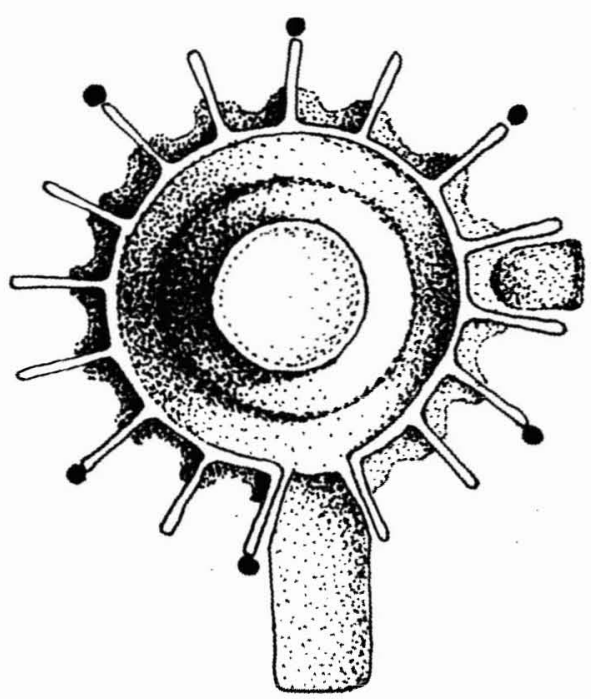

Fig. 16. Top view of the furnace.

can produce temperatures that are high enough to make glass beads and arm rings with the least possible consumption of fuel. In normal circumstances the furnace can be used for about half a year, depending entirely on how carefully it was built and maintained (Fig. 19). Thus, one sees continuous reconstruction of furnaces in

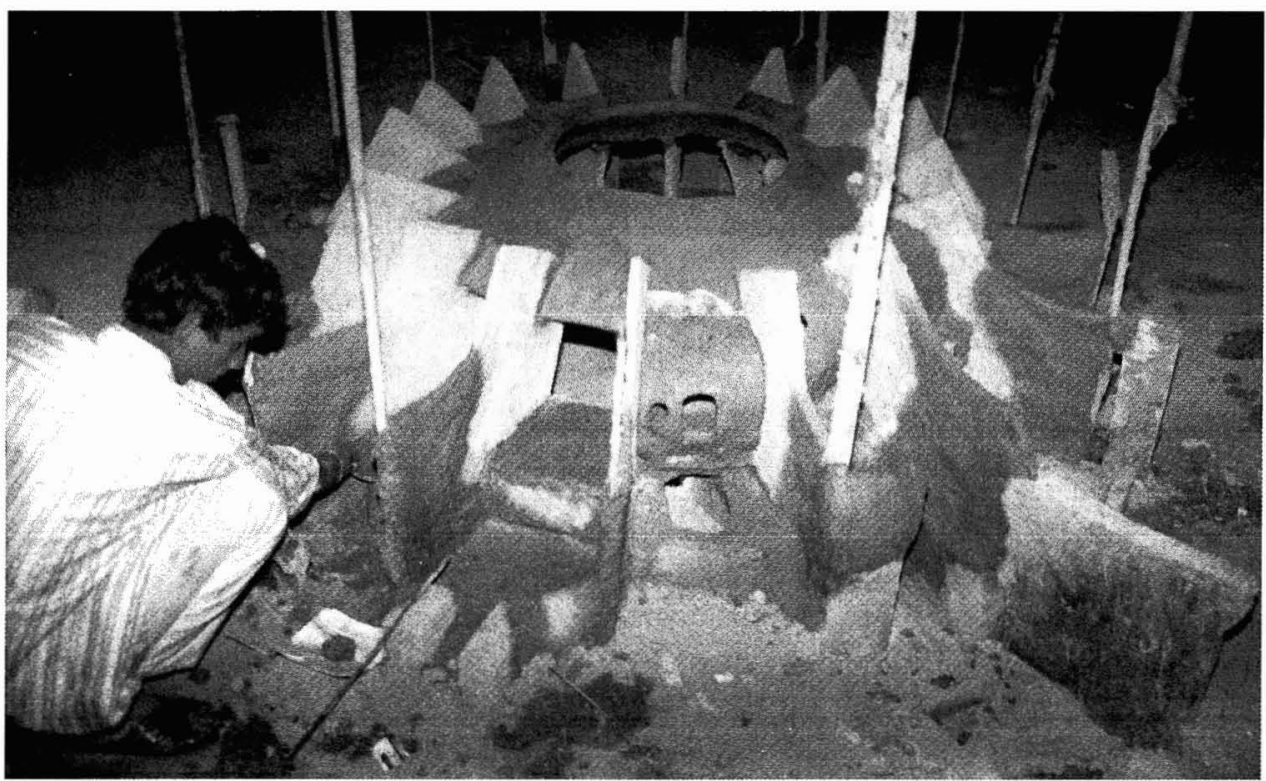

Fig. 17. Furnace construction nearing completion. 


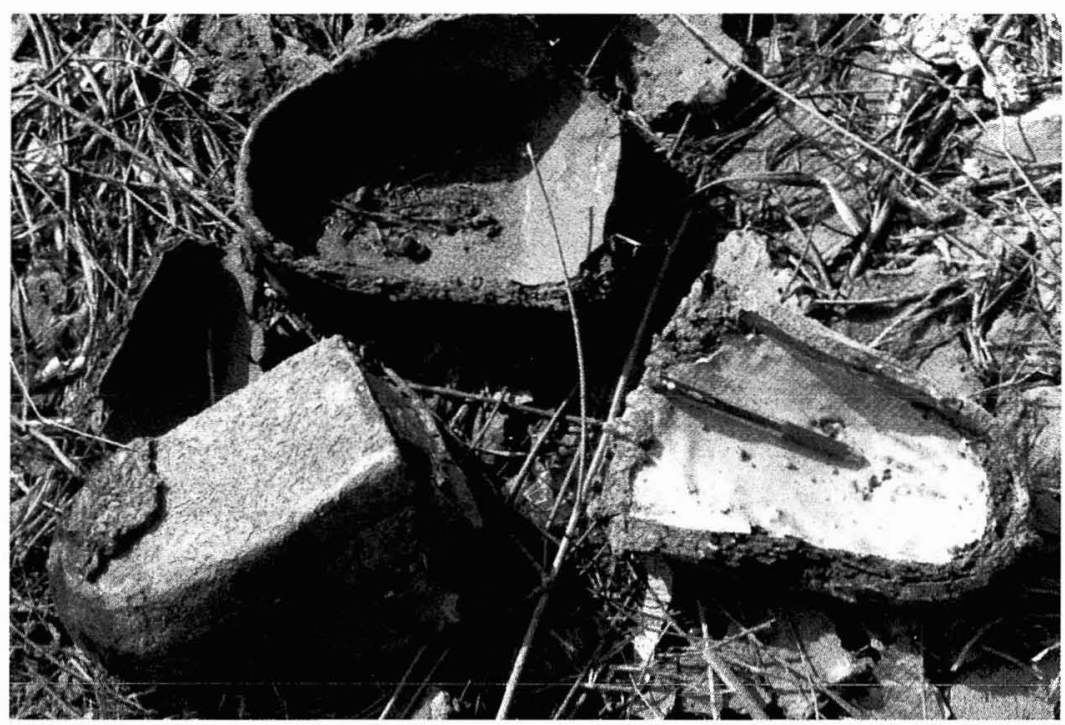

Fig. 18. Broken and burned crucibles.

the village. They are generally rebuilt in the same place after completely demolishing the earlier ones. This results in an abundance of fired-clay fragments with glass spillage, clay pots, clay plates, arm rings, broken crucibles with a glass layer, and bricks and other debitage littered around the glassworks. One can see the ac-

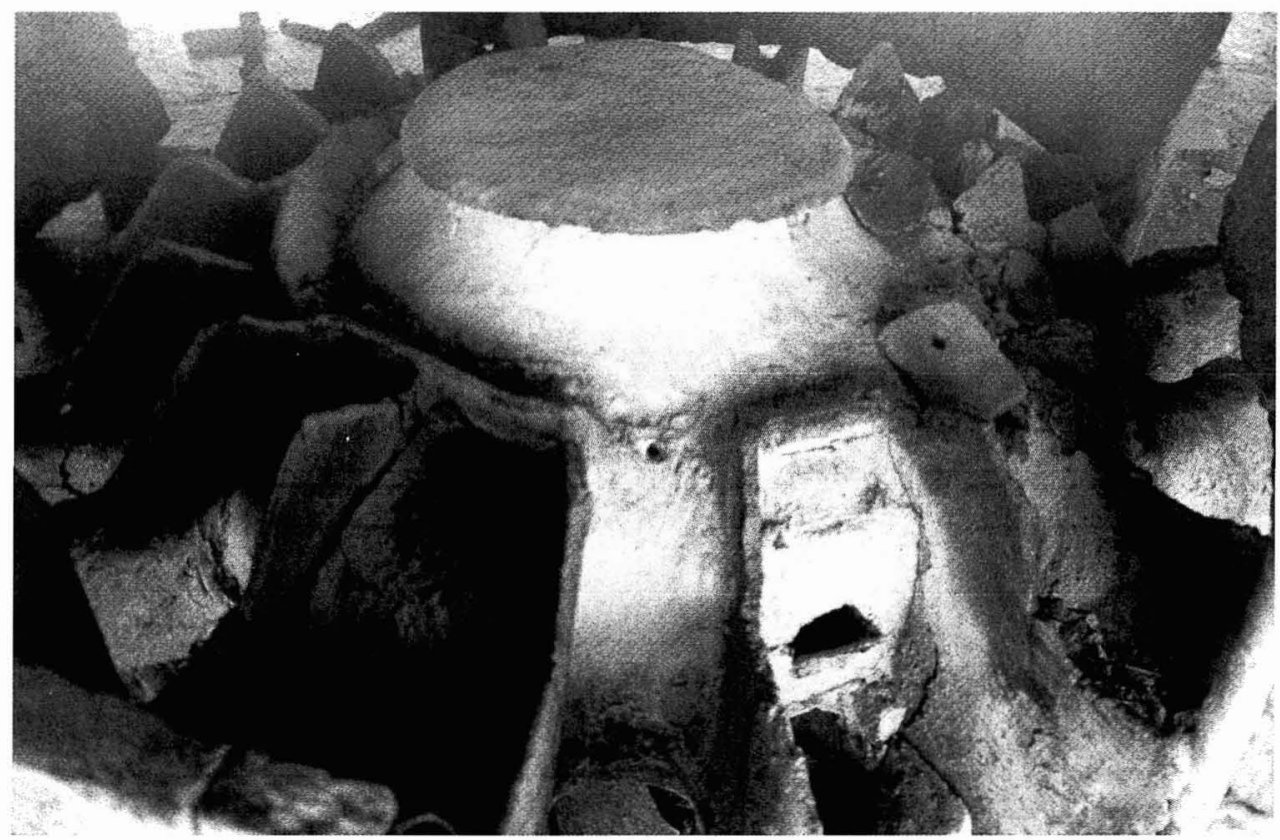

Fig. 19. A burned furnace. 
cumulation of debitage after hundreds of years of breakage and rebuilding furnaces. Once fired and broken, clay cannot be reused for furnace activities.

When work is going on in the furnace, it is fired exclusively with dry, deciduous brushwood. These quick-burning branches produce a lot of flame and thus higher temperatures, while the production of large quantities of charcoal is avoided. Dried branches are preferred to real logs because with these, one can better control the temperature of the furnace.

Work in the glassworks begins around 4 a.m., when the stroker lights the furnace with logs of wood and cow-dung cakes. It takes about an hour and a half for the furnace to reach the right temperature for the day's work to begin. An iron pipe is used to blow air into the fire. The crucibles are filled with glass either broken from new cakes or collected. It takes about half an hour for the glass to melt sufficiently for beads and arm rings to be made. Very often, new, cold glass is added at the back of the crucible while work is going on from the front. When this has melted, the beadmaker mixes it well and pulls it to the front of the crucible with a stirring iron.

There is no age restriction for the beadmakers; they are a mixed age group ranging from seven years upward. Generally one of them keeps singing movie songs mixed with various risqué expressions. Bawdy singing is not merely an entertaining option, but is considered imperative for a productive and enjoyable working session! The prevailing mood at such sessions being what it is, any query put to a worker at that time brings forth a risqué double entendre as a response.

Once the pots cool down, the beads are taken out for temporary cleaning and sorting, and the debitage, consisting of cracked beads and closed perforations, is thrown nearby. This is the job of children and elders alike.

\section{THE RAW MATERIAL}

Raw glass in cake form comes from the glass furnaces of Firozabad, about $70 \mathrm{~km}$ from this village. Pouring the liquid glass over a heavy plate of stone or iron from a crucible scoop and exposing it to rapid cooling makes it brittle and thus easy to break when it is to be used. Some glassworkers of the Purdalpur village melt various pieces of cast-off glass together and produce colored cakes of raw glass that they either sell or keep for later use. These glass cakes are broken into pieces before putting them into the bead furnace. The beadmaker who goes to the glass furnaces always takes beads along with him to the factory for color matching and very often, he leaves these behind in the factory.

\section{THE TRADERS}

At Purdalpur there is a section of people who generally do not themselves produce beads, preferring to play the role of middlemen for the traders in big cities like Varanasi, Delhi, Mumbai, Hyderabad, and Bangalore. There are a number of local traders in Purdalpur village, but generally none of them sends beads to the international market directly. BBL, which is the biggest trader of glass beads in India, has a main office at Varanasi and has been dealing with international trading of both lamp-wound beads (own production) and furnace-wound beads ordered through Ashok Upadhyaya of Purdalpur, or other smaller dealers. Ashok 


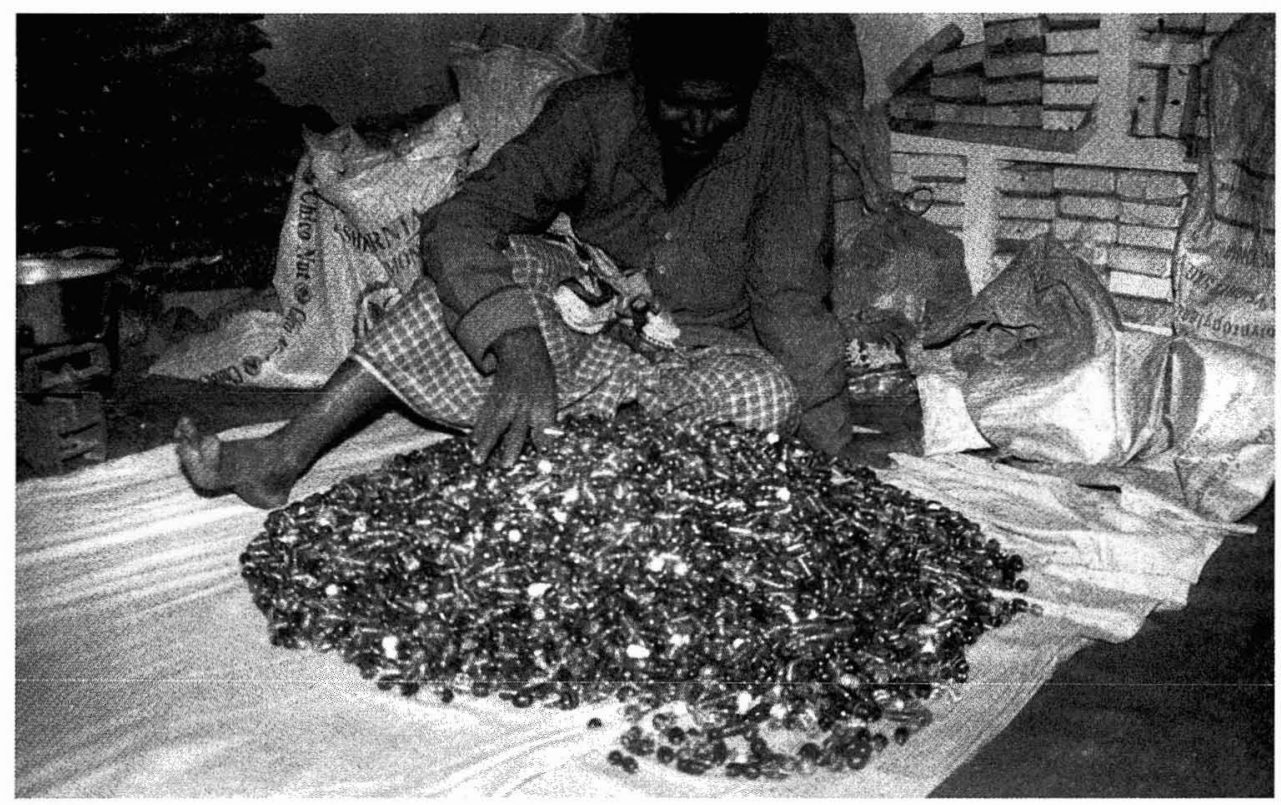

Fig. 20. A beadmaker with his beads at Upadhyaya's shop.

Upadhyaya is a middleman for the BBL and also sends beads to other cities. The details of this middleman's modus operandi and BBL's network are presented below as a case study.

Orders for specific bead styles come to Ashok Upadhyaya; the beads are either designed by the BBL or by its clients from various parts of the world. Villagers from different furnace houses come empty handed to Upadhyaya and go away with the models, orders for specific quantity, glass and mold/dye (if required), and sometimes even with advance payment. After they complete the job they take the beads back to Upadhyaya and the process of quality assurance and weighing the products takes place before the balance of payment is made and new orders are placed (Fig. 20). Beadmakers resort the beads from the debitage, like half molded, closed perforation, cracked beads, beads with air bubbles, and transportation debitage, all of which is generally thrown away nearby, leading to the accumulation of debitage near a place where the beads are not actually made. However, slag fragments are not found here. But transportation of raw glass from here to the workers' place, and beads brought from the furnace without proper packing, results in pieces of them being found in the nearby debitage. Sometimes new shapes, rather than the targeted one, are invented accidentally while winding the beads in a different manner. The author witnessed one such piece, sorted by a beadmaker into the debitage in Upadhyaya's house-cum-shop, which came to be so appreciated that more beads of that type were ordered. In the case of complexly designed pendants, payment is made on the basis of number rather than weight. Out of $3.5 \mathrm{~kg}$ of beads, 66 pieces weighing $75 \mathrm{~g}$ were debitage, and most of them were claimed to be broken in transit (Fig. 21). 


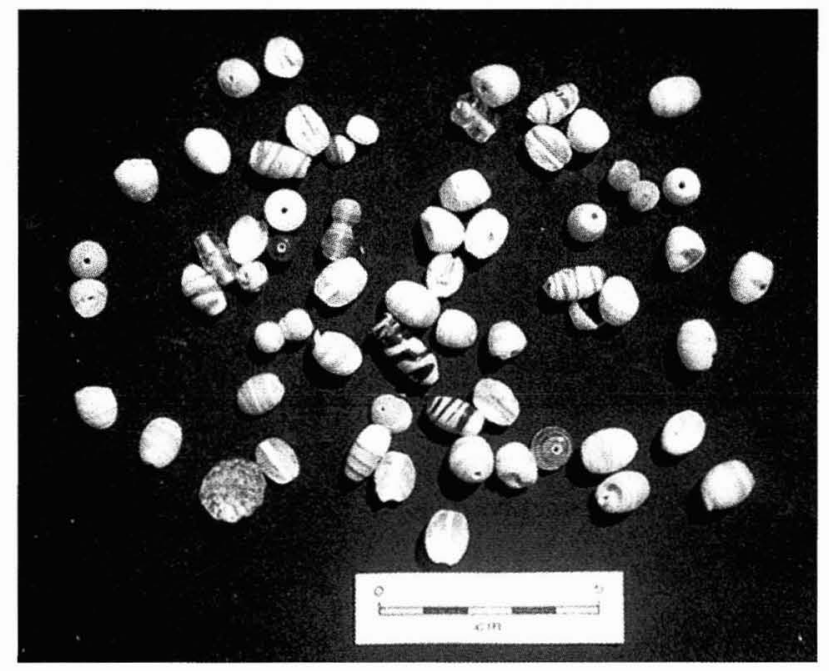

Fig. 21. Transportation debitage.

There are many people in the village engaged only in mold/dye making (Fig. 22). One finds plenty of models of beads with them. These models may have traveled from almost any part of the earth, and might be different colors. The same applies to the model that goes to the local furnaces to be copied as per the end client's requirement. Interestingly enough, the dyemaker generally breaks the model beads into two parts to make the mold/dye more accurately. This also becomes a location for bead debitage.

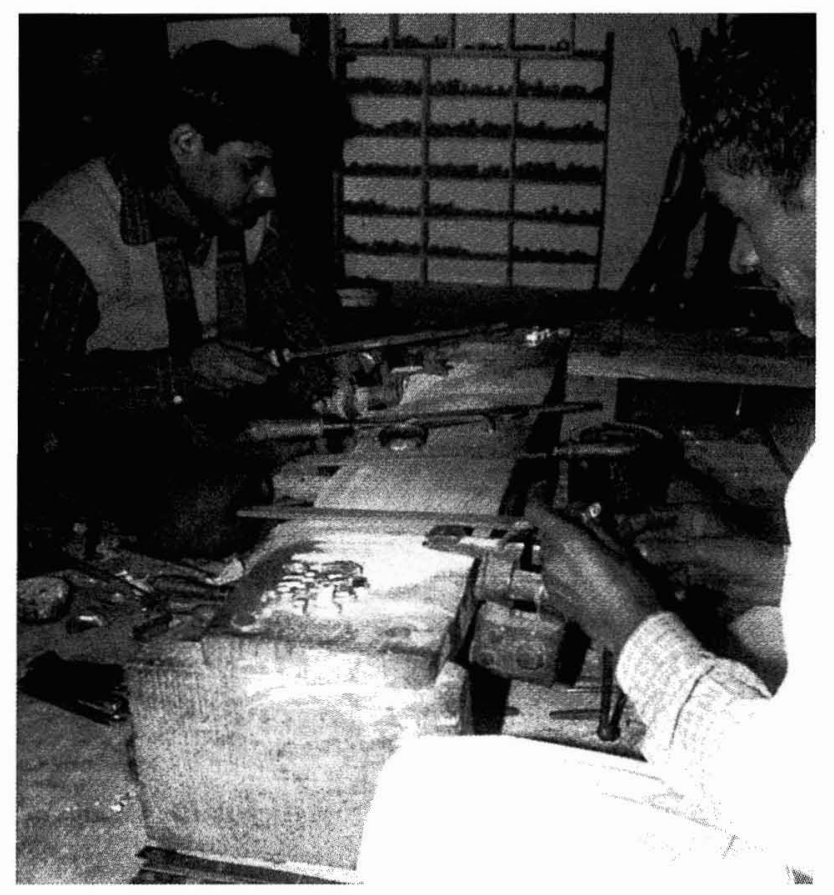

Fig. 22. A mold-making shop at Purdalpur. 


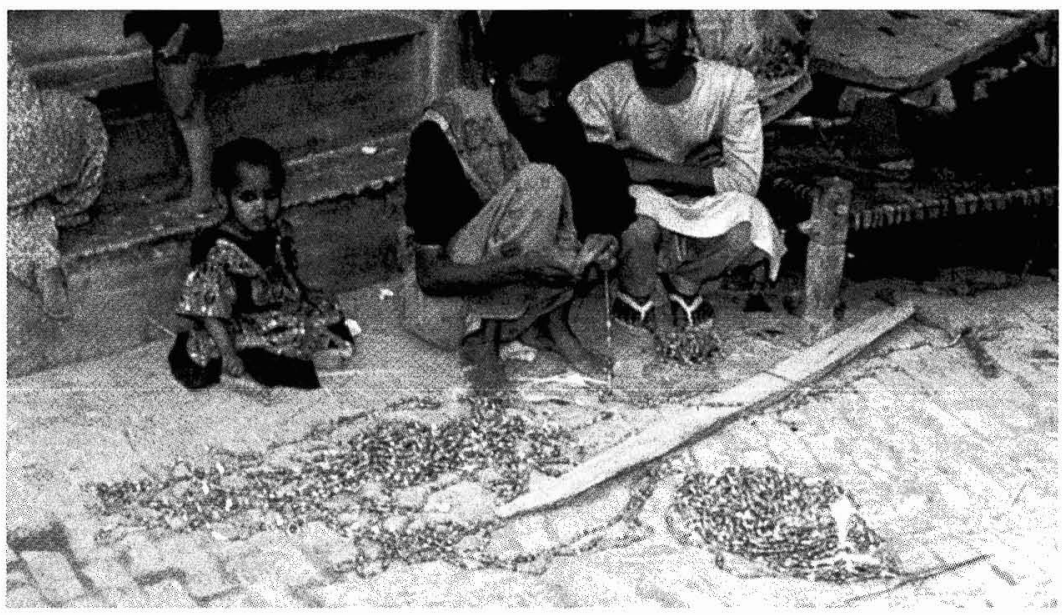

Fig. 23. Stringing beads at a nearby village.

BBL exports worldwide an astonishing 50,000 varieties of glass beads. It exports wound beads to over 50 countries, including Japan, China, Hong Kong, Thailand, Philippines, Lebanon, Syria, Jordan, Saudi Arabia, Australia, Senegal, Ivory Coast, Kenya, South Africa, countries of Western Europe, USA, and Canada. However, 50 percent of the export is to the United States (Kanungo 2001c: 101).

\section{STRINGING AND CLEANING BEADS}

Once the beads come to BBL, they are cleaned thoroughly and polished or rubbed on a gunny sack or coir mat. In the process of cleaning the perforation, which is done by pulling the bead forward and backward on an aluminum wire fixed to the ground and some chemical treatment, a few of the beads break apart. The cleaning is also done at village level. After sorting, the beads are either packed for export or sent to different neighboring villages for stringing (Fig. 23). In the latter case, they are sorted more efficiently according to their symmetry, and most of the unfinished, half finished, or odd pieces are discarded, leading to the accumulation of material in the village where stringing takes place rather than at the production center. The same procedure is followed in the case of beads that are sold directly from the Purdalpur traders. Once sold or exported unstrung, it is not unlikely that bead debitage will be found at the end-user's or stringer's place (Kanungo 2001a, 2001b, 2001c).

A center like BBL is not the bead production center, but a trading complex, which gets the orders, and forwards them to Purdalpur bead producers via middlemen. Furnace workers and mould makers get the foreign material, despite lacking any direct contact or knowledge of BBL's export. In accordance with this observation, it is likely that in ancient India too decentralization of bead production was followed, with control over trading activity being maintained in a geographically important place. This could be one of the reasons why such a large 
number of bead production centers in ancient India have purportedly been found. Rather than insisting on their being "manufacturing centers," we may consider the ethnographic data discussed in this paper, which demonstrate that glass beads are found in the varied locations listed below, and reexamine such sites.

1. Production place.

2. Middlemen and trader's place.

3. Place of cleaning.

4. Re-annealing and glazing place.

5. Transportation route (due to a hole in the sack, which is very common).

6. Glass factory where the beadmaker generally takes some debitage to get glass of same color.

7. Quality assurance sorting place.

8. Moldmaker's place.

9. User's place.

10. Village nullahs.

Because trading by sea was relatively more secure and land routes were limited, the coastal sites would have played a major role in trading activities like that of BBL. Presently, the actual production takes place at a village, Purdalpur, about $250 \mathrm{~km}$ from the trading center BBL, at Varanasi (probably due to its commercial location). Thus BBL is likely to have less debitage than that observed in surrounding village centers. In contrast, in the villages, the finished products will be fewer in number, as they are brought back to BBL for export.

There have been a number of claims for different sites to be glass-producing centers, based on the discovery of large quantities of beads or debitage. The claims are based on statistics rather than on scientific observation of beadmaking processes. No archaeological site has yet to provide evidence of a glass bead furnace and none should claim to be a glass bead production center of all varieties of beads unless sufficient evidence is found.

Given that glass beads constitute an important artifact with a high survival rate, and of a size and usage pattern that ensures wide dispersal, it is important to correlate archaeological evidence with current knowledge of bead production processes. In doing so, we begin to understand how the entire life-cycle of beads, from the first stages of production to the various end uses, traverses a spatially wide area, with the possibility of "debitage-like" deposits accumulating at various stages. However, while the beads, once produced, tend to "travel" to distant places, their production requires a complex web of processes, techniques, and skills that are likely to be available at only a limited number of locations. Thus, the dispersal is of the artifact, not of the whole web of production processes, implying that care has to be exercised before any site with bead debitage can be considered a bead "production center."

\section{ACKNOWLEDGMENTS}

The author is grateful to the small study and research grants (India), Nehru Trust for the Indian Collections at the Victoria and Albert Museum, for financial support; to the Deccan College Post-Graduate Research Institute Library, India, for academic support; to Mr. Ashok Gupta, Chairman of BBL for his cooperation; to Profs. V. N. 
Misra, V. D. Gogte, and Mr. Vinish Gupta for thoughtfully going through the earlier draft of this paper; to Mr. Devadatta Phule for help with the line drawing, and to Dr. Shahida Ansari for help with the map.

\section{REFERENCES CITED}

Abdurazakov, A. A.

1987 Indian and Central Asian connections, in Archaeometry of Glass: 37-43, ed. H. C. Bhardwaj. Calcutta: Indian Ceramic Society.

Annual Report of the Archaeological Department of his Exhalted Highness the Nizam's Dominions.

1936- Calcutta: Baptist Mission Press.

1937

BASA, K.

1993 Manufacturing methods of monochrome glass beads in South Asia. Man and Environment 18(1): $93-100$.

Chaudhuri, $\mathrm{M}$.

1986 The knowledge of glass and glassmaking in ancient and medieval India, in Technology in Ancient and Medieval India: 93-105, ed. A. Roy and S. K. Bagchi. Delhi: Sandeep Prakashan.

Deo, S. B.

1960 Objects of glass, in From History to Pre-history at Nevasa (1954-56): 441-453, ed. H. D. Sankalia, S. B. Deo, Z. D. Ansari, and Sophie Ehrhardt. Poona: Deccan College PostGraduate and Research Institute.

1971 Beads, in Chalcolithic Navdatoli: The Excavation at Navdatoli 1957-59: 351-368, ed. H. D. Sankalia, S. B. Deo, and Z. D. Ansari. Pune: Deccan College.

1987 Early Indian glass: Antiquity and archaeology, in Archaeometry of Glass: 76-79, ed. H. C. Bhardwaj. Calcutta: Indian Ceramic Society.

2000 Indian Beads: A Cultural and Technological Study. Pune: Deccan College Post-Graduate and Research Institute.

Dikshit, M. G.

1952a Beads, in Excavations at Brahmapuri (Kolhapur) 1945-46: 87-114, ed. H. D. Sankalia and M. G. Dikshit. Deccan College Monograph Series: 5. Poona: Deccan College PostGraduate and Research Institute.

$1952 b$ Some Beads from Kondapur. Hyderabad: The Archaeological Department of the Government of Hyderabad.

1952c Beads from Ahichchhatra. Ancient India 8:33-63.

1964- Studies in ancient Indian glass-I glass as mentioned in Kautilya's Arthasastra, East and 1965 West, n.s. 15(1-2):62-68.

1969 History of Indian Glass. Mumbai: University of Bombay.

Dubin, L. S.

1987 The History of Beads. London: Thames and Hudson.

FRANCIS, P.

1983 Some thoughts on glass bead making, in Proceedings of the 1982 Glass Trade Bead Seminar: 193-202. Research Notes No. 16. New York: Rochester Museum and Science Center, Rochester.

1987 Bead Emporium: A Guide to Beads from Arikamedu in the Pondicherry Museum. Pondicherry: Museum Publications No. 2.

$1990 a$ Glass beads in Asia, part I. Introduction. Asian Perspectives 28(1):1-21.

19906 Glass beads in Asia, part II. Indo-Pacific beads. Asian Perspectives 29(1):1-23.

1991 Bead making at Arikamedu and beyond. World Archaeology 23(1):28-43.

199220 Easy Steps to Identifying Most Beads in Most Collections. New York: Lapis Route Books.

1994 Towards a social history of beadmakers. Beads 6:61-80.

2002 Asia's Maritime Bead Trade 300 B.C. to the Present. Honolulu: University of Hawai'i Press.

n.d. The beads and other small finds, in The Ancient Port of Arikamedu: New Excavations and

Researches 1989-1992, vol. II, ed. Vimala Begley. Paris: Memoires Archeologiques, Ecole

Francaise d'Extreme-Orient.

GAUR, R.

1983 Excavations at Atranjikhera. Delhi: Motilal Banarasidas. 
GHosH, R.S.M.

1924 The use of glass in ancient India. The Journal of the Bilar and Orissa Research Society' $10(3): 194-201$.

Gupta, S.

1999 Indo-Pacific beads in Japan. Bead Study Trust Newsletter 34:11-14.

2000 New analysis of Indo-Pacific beads and glass waste from Arikamedu, India. Bead Study Trust Newsletter $35: 8-9$.

Gururaja Rao, B. K.

1970 Development of technology during the Iron Age in south India. Indian Journal of History of Science 5(2): 253-271.

Indian Archaeology: A Review

Volumes for 1959-1960, 1963-1964, 1972-1973, 1974-1975, 1979-1980, 1980-1981, 1981-1982, 1982-1983, 1986-1987, 1987-1988, 1988-1989, 1989-1990, 1990-1991, 1993-1994, and 1994-1995. New Delhi: Archaeological Survey of India.

JosHI, J.

1993 Excavation at Bhagwanpura 1975-76 and other Exploration and Excavations 1971-1981 in Haryana, Jammu and Kashmir and Punjab. Delhi: Archaeological Survey of India.

KANUNGO, A. K.

2000 Bondo costume ornament. Ornament 23(4):20-21.

$2001 a$ Glass beads in Indian archaeology - an ethnoarchaeological approach. Bulletin of the Deccan College Post-Graduate and Research Institute 60:337-353.

20016 Beads of Juangs. Beads 8-9:3-10.

2001c Glass beads in India: Lamp winding and moulding techniques. Man and Environment 26(2): 99-108.

$2002 a$ Glass Beads in Ancient India: An Ethnoarchaeological Approach. Ph.D. diss., Deccan College Post-Graduate and Research Institute, Pune.

$2002 b$ Bondo beads: An ethnoarchaeological approach. South Asian Studies 18:121-128.

Kock, J., AND Torben, S.

1995 Glass, Glassbeads and Glassmakers in Northern India. Vanlose, Denmark: Thot Print.

LAL, B. B.

1954- Excavations at Hastinapura and other explorations in the upper Ganga and Sultej basins 1955 1950-52. Ancient India 10:5-151.

1987 Glass technology in early India, in Archaeometry of Glass: 44-56, ed. H. C. Bharadwaj. Calcutta: Central Glass and Ceramic Research Institute.

Lamb, A.

1965 Some observations on stone and glass beads in early southeast Asia. Journal of the Malaysian Branch of the Royal Asiatic Society 38(2):87-124.

LugAy, J. B.

1974 Determination of the methods of manufacture of glass beads, in Proceedings of the First Regional Seminar on Southeast Asian History and Archaeology, Manila, 1972: 148-181. Manila: National Museum.

Majumdar, R. C.

1960 The Classical Accounts of India. Calcutta: Firma K. L. Mukhopadhyay.

Marshall, J. H.

1915 Excavations at Bhita, Archacological Survey of India Annual Reports 1911-12: 29-94. Calcutta: Superintendent Government Printing.

1951 Taxila. 3 vols. Cambridge: Cambridge University Press.

Mukharji, T. N.

1888 Art-Manufacturers of India. Calcutta: Superintendent of Government Printing, India.

PLINY

1857 Natural History' (Loeb's ed.), 6 vols., trans. Bostock and Riley. London.

RamaCHANDRAN, K. S.

1980 Archacology of South India-Tamilnadu. Delhi: Sandeep Prakashan.

ROY, P., AND Y. P. VARSHNEY

1953 Ancient Kopia glass. Glass Industry 34:366-392. 
Sankalia, H. D., and M. G. Dikshit

1952 Excavations at Brahmapuri (Kolhapur) 1945-46. Deccan College Monograph Series 5. Poona: Deccan College Post-Graduate and Research Institute.

Sankalia, H. D., S. B. Deo, Z. Ansari, and S. Ehrhardt

1960 From History to Prehistory at Nevasa (1954-56). Pune: Deccan College.

SCHOFF, W. H., TRANS.

1912 Periplus of Erythraean Sea. London.

Sen, S. N., and Mamata Chaudhuri

1985 Ancient Glass and India. New Delhi: Indian National Science Academy.

SINGH, A. K.

1983 Pottery and trade-a study of Roman pottery from Indian sites. Journal of the Bihar Research Society 53-54:140-174.

SINGH, R. N.

1989 Ancient Indian Glass: Archaeology and Technology. Delhi: Parimal Publication.

SLEen, W.G.N. VAN DER

1973 A Handbook on Beads. Liege: Librarie Halbert.

Srinivasan, K. R., and N. R. BANerJeE

1953 Survey of south Indian megaliths. Ancient India 9:103-115.

STERn, E. M.

$1987 a$ On the glass industry of Arikamedu (ancient Podouke), in Archaeometry of Glass: 26-36, ed. H. C. Bhardwaj. Calcutta: Indian Ceramic Society.

$1987 b$ The secret of Papanaidupet. Glastechnische Berichte 60:346-351.

1991 Early Roman export glass in India, in Rome and India: The Ancient Sea Trade: 113-124, ed. V. Begley and Richard D. De Puma. Madison: The University of Wisconsin Press.

THAPAR, B.

1957 Maski 1954; a Chalcolithic site of the southern Deccan. Ancient India 13:4-142.

Thapar, B., V. T. Athavale, K. R. Rao, and R. Shahi

1964- Prakash 1955: A Chalcolithic site in the Tapti Valley. Ancient India 20-21:5-167.

1965

Varshney, A. K., S.S.C. Tong, and V. Gogte

1988 Analysis of early glass objects from Nevasa excavations in India. Transactions of the Indian Ceramic Society 47(5):149-155.

Verma, O. P.

1974 Glass objects, in Excavations at Bhokardan (Bhogavardhana) 1973: 197-201, ed. S. B. Deo. Nagpur: Nagpur University and Marathawada University.

WHEELER, R.E.M

1947- Brahmagiri and Chandravalli 1947: Megalithic and other cultures in the Chitaldurg dis1948 trict, Mysore state. Ancient India 4:181-310.

Wheeler, R.E.M., A. Ghosh, And K. Deva

1946 Arikamedu: An Indo-Roman trading station on the east coast of India. Ancient India $2: 17-124$.

\section{ABSTRACT}

Today glass beads are a major product of India from at least three different locations, using altogether different techniques. Each production process leaves behind debitage unique to its individual manufacturing process.

Archaeologically, it is imperative to identify and record the production techniques of glass bead manufacture and to identify the various specific waste products rather than merely speaking of beads and production centers on the basis of statistics.

There have been a number of studies on Indo-Pacific bead production, but few on other methods. An ancient and important technique of bead manufacture, used even today, is the "furnace-winding" technique. Beads produced by this technique have been found in large numbers at various archaeological sites. This paper dis- 
cusses the details of beads and bead waste produced by the furnace-winding technique and the specific criteria of production. It also uses the results of a detailed ethnographic analysis at a manufacturing village, Purdalpur, to understand the production and dispersal mechanisms. An understanding of these mechanisms allows us to formulate certain criteria that can be used to draw better inferences about archaeological sites in which bead debitage has been found. Keywords: Banaras Beads Limited, debitage, furnace-wound beads, India, Purdalpur. 